\title{
Apple Fermented Products: An Overview of Technology, Properties and Health Effects
}

\author{
Raquel P. F. Guiné ${ }^{1}\left(\right.$, Maria João Barroca ${ }^{2}{ }^{(}$, Teodora Emilia Coldea ${ }^{3}\left(\mathbb{D}\right.$, Elena Bartkiene ${ }^{4}(\mathbb{D}$ \\ and Ofélia Anjos 5,6,7,*(1)
}

check for

updates

Citation: Guiné, R.P.F.; Barroca, M.J.; Coldea, T.E.; Bartkiene, E.; Anjos, O. Apple Fermented Products: An Overview of Technology, Properties and Health Effects. Processes 2021, 9, 223. https://doi.org/10.3390/ pr9020223

Academic Editor: Dariusz Dziki

Received: 26 December 2020

Accepted: 19 January 2021

Published: 25 January 2021

Publisher's Note: MDPI stays neutra with regard to jurisdictional claims in published maps and institutional affiliations.

Copyright: (c) 2021 by the authors. Licensee MDPI, Basel, Switzerland. This article is an open access article distributed under the terms and conditions of the Creative Commons Attribution (CC BY) license (https:// creativecommons.org/licenses/by/ $4.0 /)$
1 CERNAS Research Centre, Department of Food Industry, Polytechnic Institute of Viseu, 3504-510 Viseu, Portugal; raquelguine@esav.ipv.pt

2 Molecular Physical-Chemistry R\&D Unit, Department of Chemistry, University of Coimbra, 3004-535 Coimbra, Portugal; jbarroca@gmail.com

3 Department of Food Engineering, Faculty of Food Science and Technology, University of Agricultural Sciences and Veterinary Medicine Cluj-Napoca, 400372 Cluj-Napoca, Romania; teodora.coldea@usamvcluj.ro

4 Department of Food Safety and Quality, Faculty of Veterinary, Lithuanian University of Health Sciences, Tilzes str. 18, LT-47181 Kaunas, Lithuania; elena.bartkiene@lsmuni.lt

5 School of Agriculture, Polytechnic Institute of Castelo Branco, 6001-909 Castelo Branco, Portugal

6 Forest Research Centre, School of Agriculture, University of Lisbon, 1349-017 Lisbon, Portugal

7 Spectroscopy and Chromatography Laboratory, Centro de Biotecnologia de Plantas da Beira Interior, 6001-909 Castelo Branco, Portugal

* Correspondence: ofelia@ipcb.pt

\begin{abstract}
As an easily adapted culture, with overloaded production in some parts of the globe, apples and their by-products are being redirected to pharmaceutical, canning and beverages industries, both alcoholic and non-alcoholic. Fermentation is generally considered to increase the bioavailability of bioactive compounds found in apple, by impacting, through a high degree of changes, the product's properties, including composition and health-promoting attributes, as well as their sensory profile. Probiotic apple beverages and apple vinegar are generally considered as safe and healthy products by the consumers. Recently, contributions to human health, both in vivo and in vitro studies, of non-alcoholic fermented apple-based products have been described. This review highlighted the advances in the process optimization of apple-based products considering vinegar, cider, pomace, probiotic beverages and spirits' technologies. The different processing impacts on physical-chemical, nutritional and sensory profiles of these products are also presented. Additionally, the harmful effects of toxic compounds and strategies to limit their content in cider and apple spirits are illustrated. New trends of fermented apple-based products applicability in tangential industries are summarized.
\end{abstract}

Keywords: apple pomace; cider; vinegar; probiotic beverage; spirit; alcoholic fermentation; malolactic fermentation; acetic fermentation

\section{Introduction}

Apple species belong to the genus Malus of the Rosaceae family, and thousands of cultivars are grown all around the world. This is in fact one of the most important economic fruit species, according to the Food Agriculture Organization (FAO). The last available statistics from FAO are for the year 2018 and they report that at worldwide level the area for apple cultivation was 4904 thousand ha with a total production of 86,142 thousand tones, representing a trade value of around 8 billion US\$ [1-3].

Apples are extensively consumed in all countries around the world, being very popular because of their appreciated taste, juiciness, color, texture and nutritional contribution. Additionally, they have a good preservation capacity, they are available year-round in markets, at relatively low prices and they are seen as a healthy food [4-7]. Besides being consumed fresh, apples can also be transformed into many different kinds of apple products, according to the processing technology used [1]. Some of these apple products 
include juices [8,9], dehydrated [10-13], canned [1,14] or purées [15,16]. Additionally, other apple products are obtained through fermentation processes, such as probiotic fermented apple juices [17-19] and cider [20-22], or fermented products obtained from apple pomace generated as industrial by-products [23-26].

Fermentation is a process of transforming one substance into another, carried out by microorganisms, such as bacteria and fungi, under certain circumstances, and which can occur under aerobic and/or anaerobic conditions. The specific product resulting from a certain fermentation process is determined by the type of microorganism, the processing conditions, and the substance in which the fermentation takes place [27,28]. A successful fermentation process depends on four basic points: the microorganism or microorganisms used, the culture medium, the way of conducting the process and the stages of product recovery [29-31]. Care must be taken to ensure good compatibility between the microorganism used and the culture medium, in order to promote the conditions for the microorganism to perform the necessary metabolic functions and thus obtain the desired result. If all these factors are adequately controlled, the growth of the microorganisms will be highly effective and in this way the product synthesized will be of good quality and the production yield will be satisfactory. Among the processing conditions that must be controlled for effective fermentation to take place are the $\mathrm{pH}$, temperature, humidity, aeration (in the case of aerobic fermentation), medium bed thickness and agitation speed [32-35].

Apples are recognized as providing a high amount of bioactive compounds with health promoting benefits. They are major dietary sources of flavonoids, being particularly rich in the flavonol quercetin and its derivatives [36], which are bioactive compounds object of several studies that confirm their antioxidant [37], anti-inflammatory [38] and antimicrobial [39] properties, as well as antidepressive [40] and anticarcinogenic [41,42] effects. Additionally, these compounds also protect against arteriosclerosis [43], diabetes [44], and neurodegenerative [45], cardiovascular [46] and oral [47] diseases [48]. Other studies have demonstrated that apple compounds like phenolic acids [49], flavonols, flavones and anthocyanins [50], triterpenoids [51], pectin and pectic oligosaccharides [52] and apple polysaccharides [53] have a beneficial effect on colorectal cancer and intestinal inflammation [5]. However, the concentrations and type of bioactive molecules present in apples can vary noticeably according to species and cultivar, and depends on the climatic, agronomic, harvest and postharvest conditions as well as food processing operations and storage [36,54].

The operation of fermentation has a strong impact on the product's properties, promoting a high degree of changes, some of them related with composition and nutritional value, others with organoleptic properties and others related with the effects on the human body, namely by impacting the bioactive compounds or by adding probiotic bacteria. A great deal of fermented food products acquire, through the action of the bacteria present, characteristics that improve their health effects. The study by Peng et al. [17] analyzed the properties of fermented cloudy juices obtained from different apple cultivars, and they observed important changes in the chemical composition, sensory profiles as well as bacterial counts, according to the cultivar. In the work by Roberts et al. [18] it was postulated that fermented apple juice could be successfully used as a functional food, which is particularly suitable for consumers who seek for non-dairy probiotic beverages.

The objective of this review was to highlight the most recent developments in the field of fermented apple products, including products such as, for example, vinegar, cider and pomace. For this, different fermented apple products were selected to focus from different points of view, namely, the technological aspects related with their preparation, including the fermentation process, but also focusing on the properties of the products, like for example physical-chemical properties or sensorial properties, and finally the health effects of fermented apple products. 


\section{Methodology}

The methodology that was followed in the elaboration of this review included, in a first step, the selection of the topic to be addressed. For this, a previous search was conducted on the literature to evaluate whether such a review had already been undertaken, which demonstrated that this was a field in which it would be suitable to gather in a review paper the information available scattered around the scientific literature. After establishing the study subjects, a search was conducted on the following scientific databases: Web of Science, Science Direct, Scopus, DOAJ, Medline and Pubmed, by selecting appropriate keywords. Some criteria of inclusion were established for each of the read articles based on the relevance for the particular aspects focused on in this review, with the publication date being as recent as possible.

The bibliographic sources used for this review were analyzed using the software VOSviewer, resulting in the diagram presented in Figure 1, which resulted from the analysis of co-occurrence links between keywords, considering those keywords that appeared at least twice. In Figure 1, the size of the circles and the corresponding label represent the number of keyword occurrences, while the relations between the keywords are given by the proximity of circles/labels, and were established according to the number of sources in which those keywords occurred jointly [55]. The results in Figure 1 indicate that the most relevant keywords were cider (24 occurrences), fermentation (20), volatile compounds (14), polyphenols (13), quercetin (13), humans (13), apple pomace (11) and lactic acid bacteria (10).

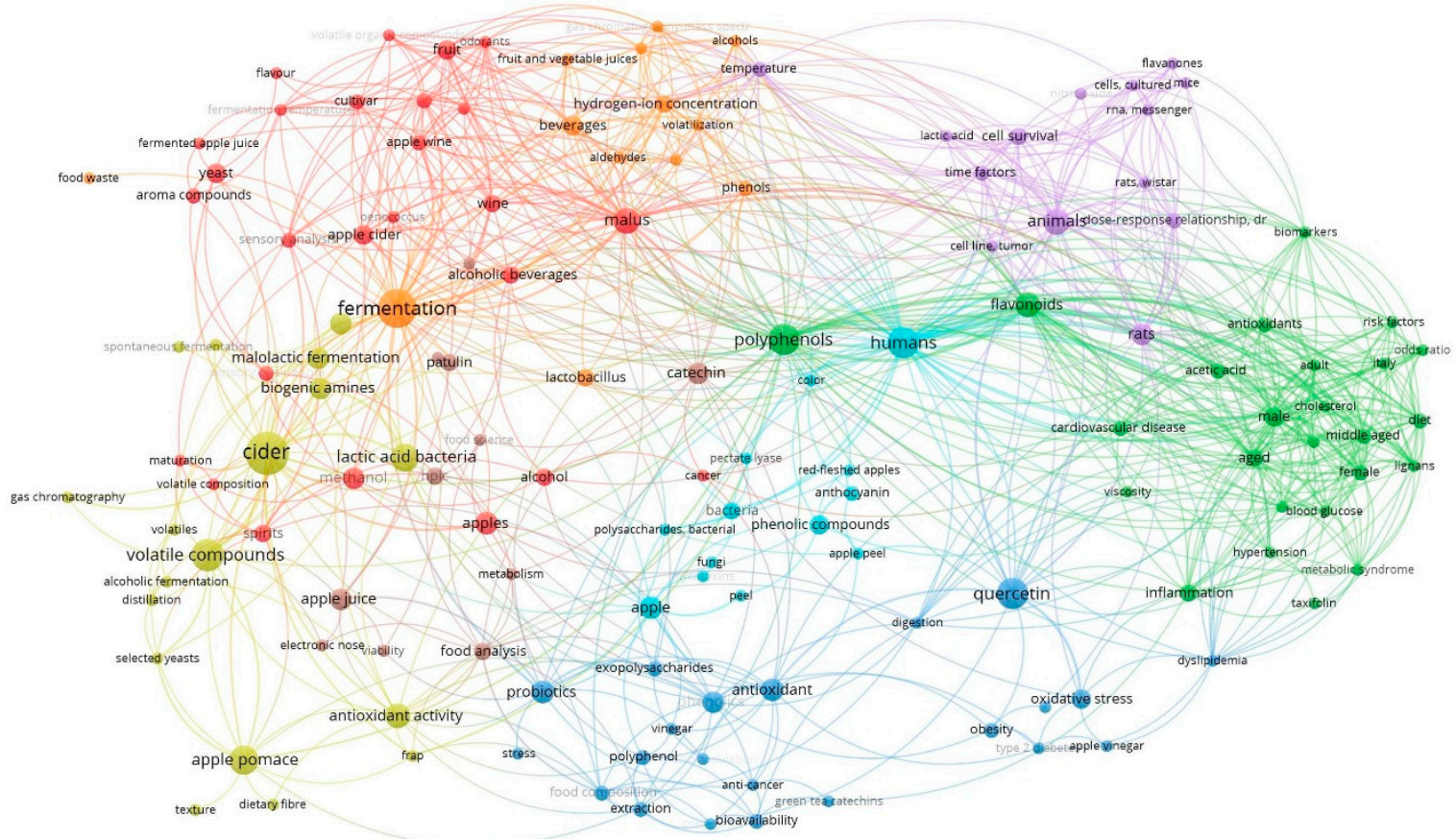

Figure 1. Analysis of co-occurrence links between keywords, selecting those that occurred at least twice.

\section{Fermentation Technology Applied to Apple Products}

Fermented apple beverages are very common in different countries around the world with some specificities. According to Figure 2, it is possible to produce many different products from apple using a fermentation process. Many of the products can be obtained directly from the fruit or the juice, while others are produced from apple pomace, which is the solid residue obtained after juice, cider, jam and vinegar production. This byproduct can be used as a raw material in many other food products, improving their commercial value and health benefits [56]. 


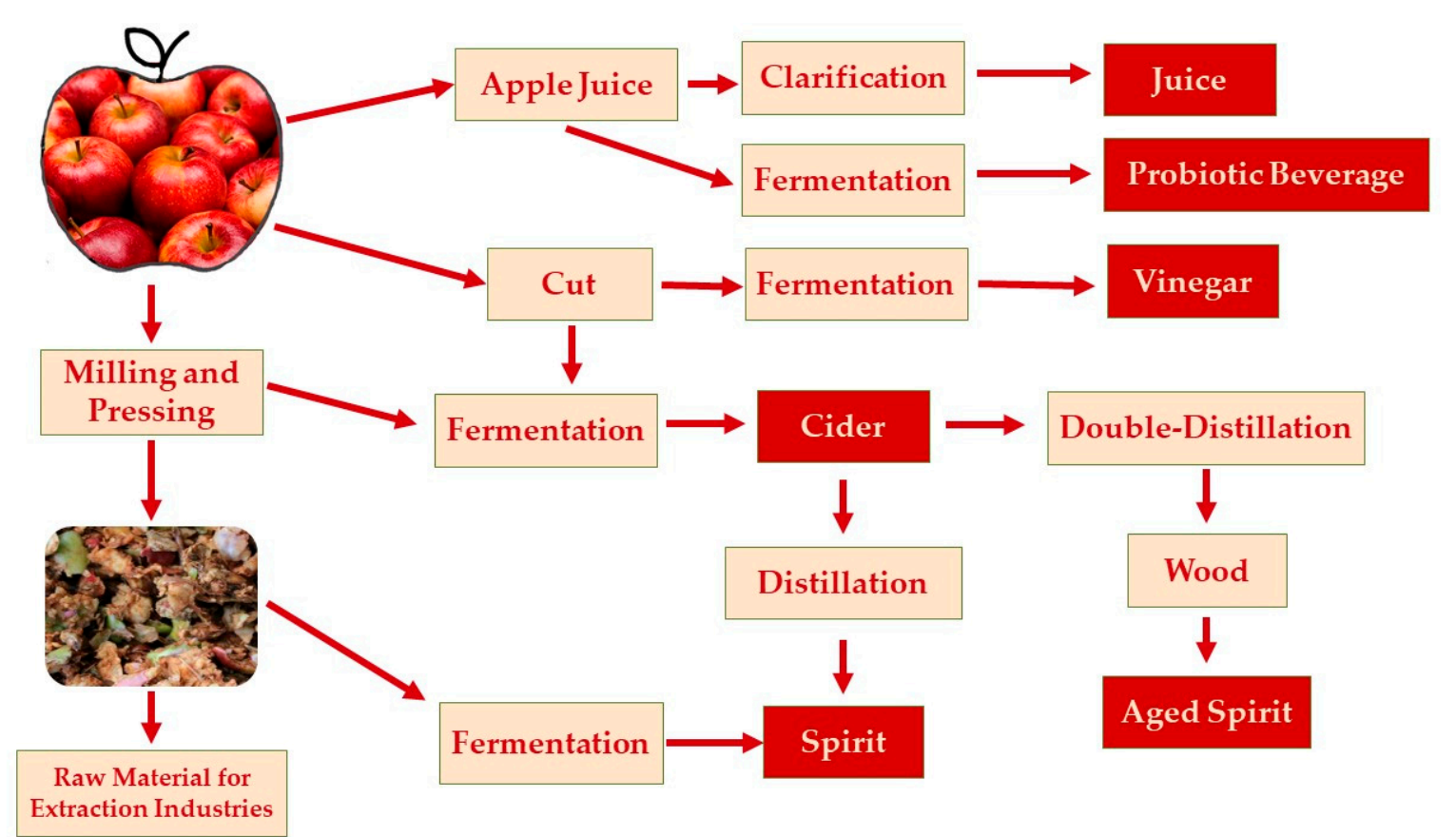

Figure 2. Fermented apple products.

\subsection{Apple Pomace}

Fruits that do not present good quality for consumption in natura generate large amounts of residues, composed of peel and pulp (95\%), seeds (2\% to $4 \%)$ and stems (1\%) [57]. Apple pomace can be used as raw material in other food products, like for example apple pomace spirits [58], or used as a source from which to extract valuable components, such as pectin [59], aroma compounds [60], edible fibers [61,62], and antioxidant polyphenols [63], or to obtain protein-enriched feeds [64], to synthesize pectolytic enzymes [65], or to produce natural aroma compounds by fermentation [66].

The nutritional composition of apple pomace differs according to the fruit variety used in the industrial process and the juice extraction processes applied. Despite the above-mentioned differences, this residue presents high moisture content, high amount of carbohydrates such as cellulose, hemicellulose, lignin and simple sugars (glucose, fructose, and sucrose), small amounts of minerals, proteins, vitamins, besides being a natural source of pectic substances [67-69].

Given its nutritional value, apple pomace has been used for fermentation, mainly solidstate fermentation, because it contains all the nutrients necessary for the microorganisms to grow.

Apple pomace extract was used as a carbon source in an aerobic-fed batch process [70] for the production of baker's yeast. The results of this work showed that the dough-raising capacity of the baker's yeast grown on the apple pomace extract was kite the same as that of commercial yeast, so, apple pomace extract could be used as a substrate providing carbon for baker's yeast production.

Wang et al. [71] studied the applicability of apple pomace as a natural stabilizer to increase the consistency and cohesiveness in yoghurt fermented with a mixture of Streptococcus thermophilus and Lactobacillus delbrueckii subsp. bulgaricus.

Given that apple pomace contains approximately $84.7 \%$ carbohydrate, $5.6 \%$ starch, and $54.2 \%$ total sugar [72], it could also be used in the production of alcoholic beverages or flavorings. Ricci et al. [73] in their studies concluded that the fermented apple pomace could be used as beer flavoring. In this case, the applicability of fermented apple pomace induced a more complex aroma profile, making it a viable option to aromatize alcoholic beverages, such as beer. Cider is mainly produced directly from the apple fermentation, as 
mentioned above; however, according to Li et al. [74], apple pomace can be added to this beverage as a fruity flavoring. Additionally, Madrera et al. [75] in their study concluded that fermented apple pomace can be used as a natural flavoring in beverages.

Apple pomace is also used to produce alcoholic beverages. The pomace spirits could be produced by fermentation of apple pomace with their indigenous microflora followed by a subsequent distillation [76], or by adding commercial yeasts. Madrera et al. [58] made apple spirits from dry apple pomace and the yeast strains used in this process were Saccharomyces cerevisiae, Hanseniaspora uvarum and wine dry yeast with B-glucosidase enzyme [58]. The spirits were distilled twice, until an alcohol strength of $60 \%(v / v)$. In this case, it is very important to pay attention to the methanol content in the final beverages given the higher amount of pectins in the raw material [77].

\subsection{Cider}

The specific definition of cider is country dependent. In some countries where the cider production dates back centuries, cider definition and labelling is well defined, while in other countries, such as Eastern European countries, where the latest statistics place cider as the fastest growing market [78], the regulation is still adapting. According to European Cider and Fruit Wine Association, cider may be defined as an alcoholic beverage obtained exclusively by the complete or partial fermentation of fresh or concentrate apple juice. Apple cider alcohol content may vary within the range of $1.2-8.5 \%$ of alcohol by volume (ABV), and should maintain the character of the fermented apple juice. On the market there are also reduced-alcohol ciders, such as alcohol-free cider, containing less than $0.5 \% \mathrm{ABV}$, and low-alcohol cider, with alcohol content between 0.5 and $1.2 \% \mathrm{ABV}$. Among modern ciders, there are flavored ciders (that besides the apple base contain juices of other fruits, extracts and flavorings) and ice ciders (made without the addition of water, sugar or alcohol).

With the worldwide increase in the production of apples, processing the fruit into cider is becoming an important and a promising trend. The processing of apple cider consists of few steps: apple washing, apple sorting, crushing (small pieces of 4-5 mm thickness) and pressing in order to separate the apple juice, followed by clarification and depectinization, yeast inoculation, alcoholic fermentation, nutrient addition for the lactic acid bacteria (LAB), malolactic fermentation, stabilization and maturation (wood ageing, optional). The aroma composition of apple cider differs based on geographical provenance, apple cultivars, apple native bacterial diversity or types of microorganisms used for fermentation, as well as the processing methods applied.

Even though the consecrated cider assortments are the English and French ones, the cider market is continuously changing, and new variants are being developed. Recent studies have tested the use of unconventional apple cultivars such as dessert apples with good results in terms of quality and consumer preference $[79,80]$. Sparkling cider, a specialty product obtained by the secondary fermentation of ciders in bottles ("Champenoise method") has been the subject of several studies [81-83].

Given the seasonality of apples, as a mainly cost-efficient alternative to fresh apple juice, the concentrated apple juice may be successfully used in cider making. When using concentrated apple juice, better results are obtained when the fermentation medium is supplemented with nutrients [84].

The pre-fermentation treatments made to apple juice prior to fermentation can significantly influence the quality of apple cider [85]. While centrifugation has only a minor effect on the phenolic content of apple juice, the oxygenation of juice strongly contributes to a decrease in all classes of native polyphenols [86], especially of catechins and procyanidins.

A key aspect during the alcoholic fermentation is the optimal consumption of nutrients by the yeast. By defining the optimal moment for biomass removal [87] or by applying the ultrasound-assisted fermentation [88], the degree of nutrient consumption for a high quality apple cider was determined. 
Several fermentation yeasts have been tested to evaluate the cider volatile compounds: S. cerevisiae, Saccharomyces uvarum, Torulaspora delbrueckii, Hanseniaspora osmophila, H. uvarum, Starmerella bacillaris and Zygosaccharomyces bailii [89]. Ciders' discrimination suggested possible strain-specific effects on the aroma fraction. Still, a recent study concluded that fermentation yeast might have little influence on the volatile profile of cider, but phenolic compositions of the juices and ciders might contribute to significant differences in astringency and bitterness sensory perceptions [90].

Apples and pears tend to have lower nutrient levels compared to grapes, which are also consumed by the $S$. cerevisiae yeasts during the alcoholic fermentation. Nutrient supplementation during malolactic fermentation is required to obtain a balanced apple cider, and consists of inactivating yeast mixtures rich in amino acids, mineral cofactors and vitamins. Those mainly responsible for malolactic fermentation in apple cider are the lactic acid bacteria (LAB) —Lactobacillus spp., Leuconostoc spp., Oenococcus spp. and Pediococcus spp. [91]. Many papers have studied the malolactic fermentation of wine [92-96], while few data are available regarding the LAB performances in cider processing [97-99]. Considering the performances of the dominant species involved in cider malolactic processes in the spontaneous cider production, the most adequate for use as a malolactic starter culture in cider production has been proved to be Oenococcus oeni, when compared to Lactobacillus collinoides and Pediococcus parvulus [98]. Good results were also obtained by using O. oeni for the deacidification of hard apple cider via the malolactic fermentation [99] or by the simultaneous malolactic fermentation using O. oeni with S. cerevisiae in the red-fleshed apple cider processing [100].

When aged in wood contact, alcoholic beverages get an improved quality and sensory profile. A study established an optimal dosage of medium toasted French and American oak chips of $4 \mathrm{~g} / \mathrm{L}$ for 30 days of wood contact [101]. Still, even though it is a common practice, the wood aging of cider is not an intensively studied topic.

\subsection{Vinegar}

In ancient times, fermentation, namely acetic acid fermentation, was a practice used for food preservation. As apple harvesting regions are extremely large, apple being an easily adapted culture, apple production is overloaded in some parts of the globe. Apple-based processed products typically belong to the canning industry and the beverages industries, both alcoholic and non-alcoholic.

Considering the overproduction of apple cider, this product is often redirected to vinegar processing. Apple cider vinegar is consumed in Western European countries as a functional alcohol-free beverage. Apple vinegar, known as cider vinegar, is made with apple juice or concentrated apple juice via a double fermentation process-alcoholic fermentation followed by acetic fermentation.

Vinegar is highly consumed in the daily diet as a food flavoring agent, as a food preservative and with therapeutic objectives. Recent studies have found that acetic fermentation might improve the nutrients content and functionality. The alcoholic fermentation followed by the acetic acid fermentation change the nutritional profile of a beverage into a more complex one [102,103], even though the bio-accessibility of phenolic antioxidants from vinegar is a matter of great interest being subject of previous studies [104].

The composition is regulated by each state producers, considering mainly acidity, for which the minimum legal limit is $4 \%(w / v)$ acetic acid. Based on a traditional procedure, apple cider vinegar is made from fresh, crushed apples, then fermented, and matured in wooden barrels. Both fermentations-alcoholic and acetic-take place in the same barrel, with the spontaneous microflora (yeasts and acetic acid bacteria) contribution. The naturally occurring fermentation takes about 5-6 months to complete the entire fermentation process. The disadvantage in this case is the long process duration, incomplete or interrupted fermentation, and low acetic fermentation yield [105].

The chemical composition of apple cider, the raw material for apple vinegar production, may vary according to cultivar and harvesting areas. The European apple cider 
cultivars (at the optimal ripened stage) have total soluble solids ranging between 10 and $15^{\circ}$ Brix (average $9-11^{\circ}$ Brix), a titratable acidity of $0.12-0.31 \%$ malic acid, tannin content (responsible for the apples astringency) of 37 to $233 \mathrm{mg} / 100 \mathrm{~mL}$, pectin content of 0.25 $0.75 \%$ (the main responsible for the body or viscosity of apple juice), $\mathrm{pH}$ ranges $3.0-3.8$. The optimal ripening stage is extremely important for the apple juice quality because unripe fruits will originate juices having lower total soluble solids and less aroma, a higher content of starch and acids and a bitter or astringent flavor, while overly mature apples will give lower yields due to the difficulty in extraction procedure, and exhibit a sweeter, but flatter flavor [105].

One solution for the increase of apple juice yield could be the use the pectolytic enzymes [106]. In traditional cider processing, a system with hydraulic, roller or pneumatic pressure is used to rupture and compress the cells until the recoverable juice is separated from cellular solids. This procedure presents some difficulties, such as increase of nonsugar solids that might cause haze and color formation. The prolonged process, compared to industrial one, along with the impossibility of total avoidance of air exposure, facilitates the microbial (yeasts, molds and acid tolerant bacteria) growth, causing the shortening of apple juice shelf-life. To avoid these disadvantages, the concentrated apple juice might be used instead [84]. When preparing fermentable juice, the apple concentrate is diluted with water and the mixture is supplemented with nutrients (ammonium phosphate and thiamine) prior to the alcoholic fermentation to support the vitality of yeast. Still, when using freshly pressed apples, different blending procedures can serve to define a specific flavor profile and chemical composition of the apple juice.

Alcoholic fermentation of apple juice is mainly carried out using $S$. cerevisiae yeast (pure culture inoculation or indigenous yeasts) and other indigenous yeast species such as H. uvarum (anamorph Kloeckera apiculata) that predominate at the beginning of fermentation process and are followed by $S$. cerevisiae at the end of fermentation, and Dekkera (anamorph Brettanomyces) species during the maturation phase. The final alcohol content varies depending on the initial apple sugar content, fermentation procedure or producer (5-10\% ABV). The resulting apple cider is clarified and prepared for acetic fermentation. When cider vinegar is used to inoculate the new batch, one part of the 'mother vinegar' is added to five parts of apple cider. Increased acetic fermentation yields are recorded when pure culture of acetic acid bacteria is used. There are many processing methods for vinegar production, but only two are commercially used: the Orléans process-the traditional method for vinegar making, known as the "surface method", and "submerged culture", where oxygen is supplied in fermentation. The first method mentioned is recognized to make the best flavored apple cider vinegars, while the second is used to increase the acetic acid production and to decrease the duration of fermentation [107]. Cider vinegar might be stored and matured in wooden barrels in which case the product is impacted with respect to color and wood-derived flavor compounds [105]. Other treatments to assure the products' stability are applied, such as ultrafiltration, pasteurization and use of chemical stabilization agents (sulphur dioxide, pectin, arabic gum, citric acid, potassium ferrocyanide).

\subsection{Apple Spirit}

According the European Regulation EC 110/2008 [108], fruit marc spirits is defined as a "drink with an alcoholic strength higher than $37.5 \%(v / v)$, and a quantity of volatile substances higher than $200 \mathrm{~g}$ per hectoliter of pure alcohol, that could be produced by the distillation of fermented fruit mash, juice or pomace".

The final quality and aroma of the apple spirit, as well the methanol quantity, is related to the fruit used in the fermentation process, which could be influenced by the fruit variety, their geographical origin, ripening index and storage conditions until further processing [109-111].

To make apple spirit, firstly, it is necessary to extract the juice from the fruit, which is then fermented to produce cider. After that, it is necessary to produce a distillation (or double distillation) of the fermented juice. Although it is more usual on the market 
to find apple spirit without ageing in wood barrels, this process can be considered to improve the final quality of the beverage. Coldea et al. [112] in their study showed that apple spirit ageing for 60 days in wood impacted phenolic and volatile profiles regardless of the final beverage. The same authors concluded that the major volatile compounds were not affected by the ageing process except for 2-butanol, which increased over time. Wood ageing also accentuated some flavor compounds associated with the apple, such as isobutyl-acetate, hexyl-2-methylbutanoate and ethyl-nonaoate.

The most popular apple spirit is "Calvados", which is produced by a combination of selected fruits with an appropriate sweet, tart and bitter flavor, that are fermented to produce cider. After that, the cider is double-distilled, followed by an ageing processes in wood [113].

The aroma profile of apple spirit is highly influenced by the cider [114]. When this process is longer, the apple distillate develops an aroma with more sweet and spicy characters, higher levels of ethyl acetate, ethyl succinate, ethyl lactate, and volatiles compounds derived from bacterial metabolism, such as 2-butanol, 4-ethylguaiacol, eugenol, and 2propen-1-ol. Additionally, the yeast species influence the production and aroma of spirits namely in the aromatic composition [58].

To intensify the juice extraction before the fermentation process of apple spirit, some enzymes like pectinase can be added. However, this treatment could increase the methanol content in the beverage [115]. Additionally, if apple pomace was used in the spirit production, the methanol content could increase, given the higher quantities of pectin resulting from the apple seeds and peal. Concerning the legal limits of methanol and the problems with this compound for health, this must be very carefully monitored in the production process $[77,116]$. The selection of the yeast used in the fermentation processes could be also an important step. Some studies conclude that use of indigenous yeasts could be favorable for a low concentration in methanol in the final product [58]. Another process that could be used to reduce the methanol content of the apple spirit is to perform a pasteurization of fruit prior to alcoholic fermentation [110].

\subsection{Probiotic Fermented Apples}

Fermentation food technology is mainly used to change the flavor, odor and texture of the vegetables and fruits to increase their nutritional value, preservation capacity and decrease the needs of refrigeration and freezing [117]. Additionally, fermentation of foods could reduce some toxic compounds and produce antimicrobial substances, which increases the safety of the final product [118]. These fermented food products, with beneficial effects on human health, are usually called probiotics.

The aforementioned changes in aroma, flavor and texture are associated with the LAB that promote acidic taste, and are associated with proteolytic and lipolytic activities [119,120].

Ellendersen et al. [121] studied the best conditions in which to develop an apple juice (Gala variety) fermented with Lactobacillus casei. According the same authors, the developed beverage was characterized by a typical apple aroma from the raw material, a caramel color, and an acidic apple taste.

Dimitrovski et al. [122] developed a probiotic beverage made with apple juice and lactic acid bacterium Lactobacillus plantarum PCS 26 as fermentation agent. In this study, free and Ca-alginate-embedded bacteria were studied and authors concluded that apple juice is an appropriate raw material for the preparation of a functional drink with good sensory acceptance and appropriate shelf life.

Like for other food products, the final quality of probiotic fermented apples depends on fruits cultivars, which could influence mainly the taste and aroma of the final beverage [17]. This variation is explained by the fact that different varieties of apple have differing aroma and flavor characteristics due to their different compositions, namely total soluble sugars, organic acids and volatile compounds [123]. 


\section{Properties of Fermented Apple Products}

Fruit juices have been proposed as an alternative vehicle for LAB fermentation due to their high nutritive value with respect to vitamins, minerals, dietary fiber and antioxidant compounds. Therefore, fermented fruits with LAB can be a good and healthy alternative functional food, containing probiotics and giving better nutritional, physical-chemical and sensorial properties $[124,125]$.

The major sugars of apple juice (fructose, glucose and sucrose) can be used by LAB during fermentation for cellular growth and bioconversion into lactic acid, promoting a decrease of all the sugars after the process, particularly fructose [126]. However, the carbohydrates' metabolism in cloudy apple juice (CAJ) by a mixture of Lactobacillus spp. varies according to cultivar. In the study of Peng et al. (2021), which used nine apple cultivars, the highest total sugar consumption (fructose, glucose and sucrose) was observed in the Golden Delicious cultivar, and fructose showed a major sugar decrease during the fermentation process. Moreover, Wu et al. [127] observed that the contents of total sugars in Fuji apple juice could decrease by up to $23 \%$ during fermentation with commercial LAB strains.

Throughout the fermentation process, the LAB strains exhibit various aroma-forming activities to metabolize diverse substrates and produce different aroma compounds and organic acids that impact the balance of flavor, color, taste, chemical stability, storage quality and acceptability of final products [128]. Hence, LAB strains can exert a distinct effect on the flavor compounds produced during apple juice fermentation. The use of L. casei in Gala apple juice fermentation promoted the reduction of malic acid by $87 \%$, while the lactic acid content increased by $31 \%$ [121]. The fermentation of apple juice with four strains of LAB (Lactobacillus acidophilus, Lactobacillus rhamnosus, Lactobacillus casei and Lactobacillus plantarum) produced larger concentrations of total acids, with the corresponding decrease in $\mathrm{pH}$, but the common feature of the formation of lactic acid at the expense of decline in malic acid was most evident in the apple juice containing L. acidophilus [19]. The sharp increase of lactic acid throughout apple juice fermentation and the parallel decline of malic acid highlight that malolactic fermentation occurs during the fermentation of apple juice by LAB [127]. Lactic acid, acetic acid, and tartaric acid were the dominant acids identified in fermented CAJ from nine cultivars with a mixture of Lactobacillus spp. [17]. Tartaric acid was found in the original juice, whereas lactic acid and acetic acid were formed during fermentation. Additionally, pyruvic acid decreased over the entire storage of fermented apple juice [19]. The higher content of lactic acid at the expense of the lower values of acetic acid enhances the flavor of the fermented CAJs [129]. The changes observed during fermentation for other acids in fermented CAJs, such as succinic, quinic, oxalic, and tartaric acid contents are dependent on the apple varieties [130].

Fermentation by LAB could significantly affect the volatile profile of fruit products and, consequently, impact their aroma. In fermented clear and CAJ, around 50 volatile compounds were identified, including esters, alcohols, aldehydes, ketones and acids, among others $[17,19,127]$. Any differences in the aromatic compounds of fermented apple juice can be attributed to the apple cultivar and to the different metabolic patterns of LAB in the fermentation process, thus resulting in different concentrations of organic and volatile compounds that lead to differences in the global flavor profile of fermented juice.

Esters were one of the major aromatic components in fermented clear or CAJ that contain key contributors to fruity and sweet odor, such as hexyl acetate, ethyl butyrate, ethyl hexanoate, butyl acetate, and ethyl 2-methylbutyrate [17,19,127].

Alcohols are another large group of volatiles detected in fermented apple juice, with total concentrations at least ten times greater than the apple juice [19]. The most predominant alcohols in fermented apple juice are 1-butanol and 1-hexanol that contribute to the sensation of sweetness; 2-methyl-1-butanol, which is associated with onion aroma, malt and wine; and 2-ethylhexanol, which has floral and fruity attributes. However, the high odor-detection thresholds of these alcohols resulted in a lower contribution to the flavor, except (E)-2-hexen-1-ol, which has an odor activity value (OAV) higher than one and is 
responsible for leafy, green and walnut aromas [17,19,131,132]. New alcohols, including 2-methyl-1-propanol, isobutenylcarbinol, trans-2-hexen-1-ol, benzyl alcohol, 1-octanol, $\beta$-citronellol and geraniol, can appear after LAB fermentation and enrich the background flavors of fermented apple juice [127].

The predominant aldehydes detected in fermented apple juice are hexanal and (E)-2hexenal that can confer fatty and green leaf flavor notes $[127,130,132,133]$. Other aldehydes, namely octanal, decanal, 2-nonanal, and (Z)-2-heptenal, are present in low amounts in the fermented CAJ, but contribute to the aroma because of their very low olfactory thresholds [17].

Acids are an important group of volatile compounds that contribute to the complexity and the fruity aromatic equilibrium of fermented apple juice. Acetic acid is the dominant and characteristic flavor compound in fermented CAJ, and can help create a pungent, sharp and vinegary odor, conferring a characteristic flavor [17,134].

Ketones, characterized by intense flavors, are present in low concentrations but could synergistically contribute to the aroma profile of fermented apple juice. The major volatile ketones identified were 6-methyl-5-hepten-2-one and $\beta$-Damascenone (usually present in apple juice) and 2-undecanone, 2-heptanone and 2-nonanone, 4-heptanone, 4-cyclopentene1,3-dione, only produced after fermentation by the microbial oxidation of fatty acids or by decarboxylation pathways $[17,19,135]$.

Other compounds, such as D-limonene and eugenol, may play important roles in the unique aroma profile of fermented CAJ. D-limonene gives citrus, orange, lemon and sweet aroma, whereas eugenol provides a spicy odor [134,136].

Most of the volatile compounds associated with the typical aroma of apple juice are retained or enriched after fermentation and storage, but some new compounds like alcohols, esters, aldehydes and ketones are generated from LAB fermentation, suggesting the improvement of aroma complexity in fermented apple juice [19,127]. Table 1 summarizes the predominant compounds present in LAB fermented apple products.

Table 1. Predominant compounds present in LAB fermented apple products [17,19,121,127,131-133,135,136].

\begin{tabular}{ll}
\hline Classes & \multicolumn{1}{c}{ Compounds } \\
\hline Esters & $\begin{array}{l}\text { hexyl acetate, ethyl butyrate, ethyl hexanoate, butyl acetate, ethyl 2-methylbutyrate, hexyl butyrate, ethyl acetate, } \\
\text { methyl isovalerate, isoamyl isovalerate, methyl salicylate }\end{array}$ \\
Alcohols & $\begin{array}{l}\text { 1-butanol, 1-hexanol, 2-methyl-1-butanol, 2-ethylhexanol, (E)-2-hexen-1-ol, 2-methyl-1-propanol, isobutenylcarbinol, } \\
\text { trans-2-hexen-1-ol, benzyl alcohol, 1-octanol, } \beta \text {-citronellol, geraniol, 2-methyl-1-pentanol, 3-hexen-1-ol (Z) and }\end{array}$ \\
& 2-hexen-1-ol (E) \\
Aldehydes & $\begin{array}{l}\text { hexanal, (E)-2-hexenal, octanal, decanal, 2-nonanal, (Z)-2-hexenal, acetaldehyde } \\
\text { acetic acid, butanoic acid, lactic acid, isovaleric acid, tartaric acid }\end{array}$ \\
Ketones & 6-methyl-5-hepten-2-one, $\beta$-Damascenone, 2-undecanone, 2-heptanone, 2-nonanone, 4-heptanone, \\
& 4-cyclopentene-1,3-dione \\
Others & D-limonene, eugenol, linalool
\end{tabular}

Apple juice is also the raw material of alcoholic fermented drinks, like cider (also called apple wine in some areas), by inoculation with different species of yeasts. Cider has several sensory attributes, such as acidity, color, turbidity, odor, sweetness, astringency and foam that can vary between producers. Cider taste depends primarily on apple cultivar, whereas aroma composition of volatiles depends on fermentation conditions, yeast strains, maturation, storage conditions and variety, ripeness and concentration of aromatic compounds derived from apples [123,137-142]. Many of the aroma compounds are lost in their processing and most of the aroma compounds in cider are synthetized during fermentation, forming a specific flavor that can differentiate one cider from another [140].

The most important volatile compounds identified in juice are esters, whereas in apple ciders, a wider variety of different chemical classes was found, including higher alcohols and esters, corresponding, respectively, to $56-68 \%$ and $30-42 \%$ [141], followed by fatty acids, and to a lesser extent acids, aldehydes and ketones (Figure 3). These compounds, mainly 
produced in the alcoholic fermentation as secondary metabolites, showed an important contribution to cider aroma that could be related with sensory analysis [132,143-145].

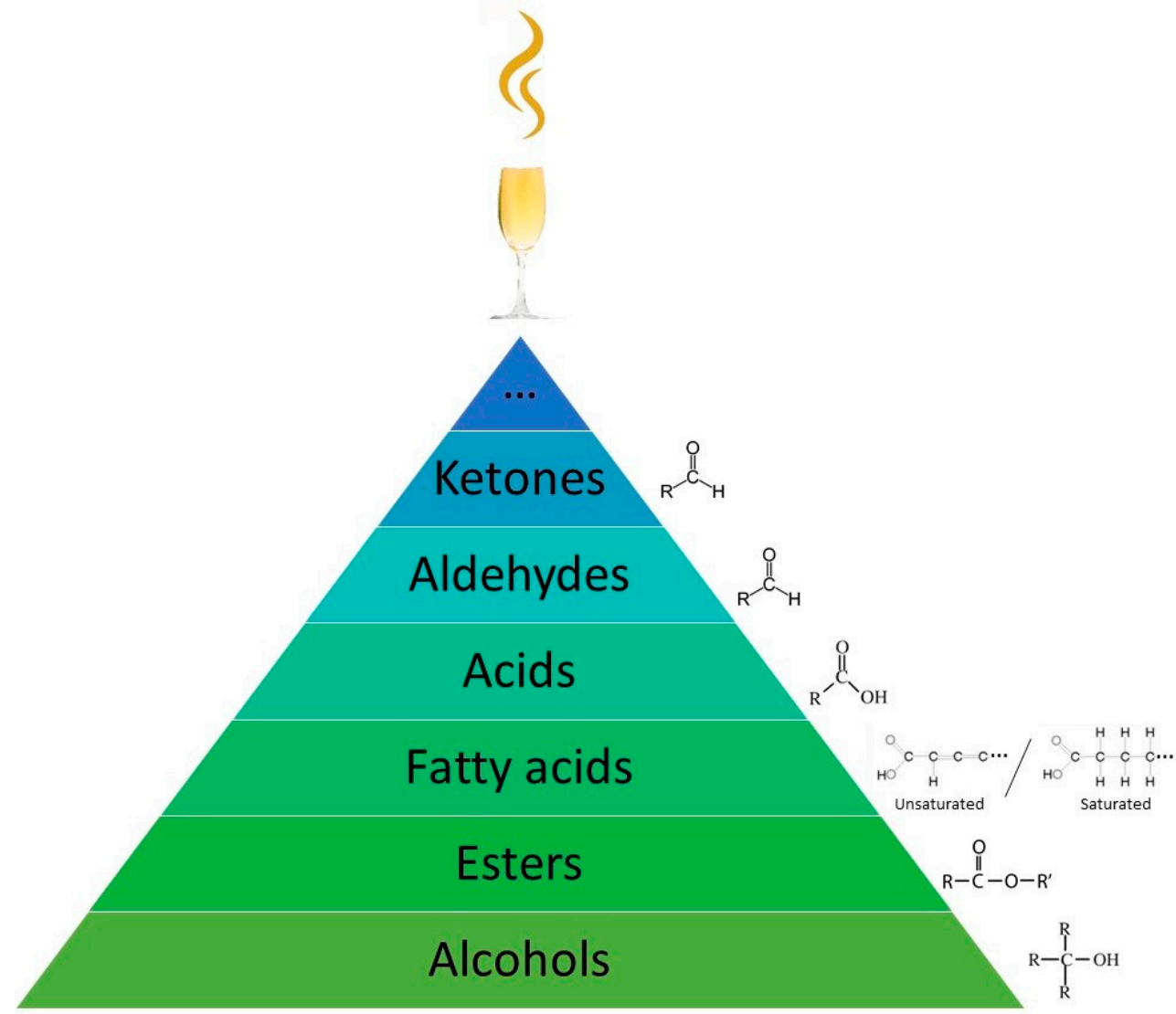

Figure 3. Major volatile compounds preset in apple cider.

The key aroma components present in ten ciders from Shaanxi (China) Fuji apple (average parameters: alcohol: 11.3 vol. $\%$; residual sugar: $3.5 \mathrm{~g} / \mathrm{L}$; total acidity: $5.7 \mathrm{~g} / \mathrm{L}$; volatile acidity: $0.7 \mathrm{~g} / \mathrm{L} ; \mathrm{pH}$ : 3.5$)$, processed with different yeasts, technological methods and apple orchards, were ethyl acetate, acetic acid isobutylester, isopentylacohol acetate, ethyl caprylate, ethyl 4-hydroxybutanoate, isopentylalcohol, 3,4,5-trimethyl-4-heptanol, nonyl alcohol, 3-methylthio-1-propanol (four esters, four alcohols, and one acid), contributing for $85.61 \%$ of the total variance in cider aroma components [140].

Rita et al. [146] identified 16 volatile compounds in yeast fermented juice aroma obtained from two apple varieties ('Lietuvas Pepins' and 'Auksis'), but the main compounds were 2-hydroxyethylhydrazine, 3-methyl-1-butanol, hexanoic acid ethyl ester and acetic acid hexyl ester. In fermented apple juice of the variety 'Lietuvas Pepins' other main alcohols-hexan-1-ol and phenylethyl alcohol-and esters-hexyl acetate, ethyl octanoate, hexyl hexanoate, 2-methylbutyl acetate-were identified [141].

Qin et al. [132] characterized the flavor profiles of 14 commercial apple ciders (ethanol content ranged from 4.5 to $7.0 \%(v / v)$, $\mathrm{pH}$ values varied from 2.91 to 3.89 , levels of titratable acidity between 2.23 and $6.39 \mathrm{~g} / \mathrm{L}$ ) from the United Kingdom and Scandinavian region. In apple ciders, it a total of 72 volatile compounds were identified, including 33 esters, 16 alcohols, 4 aldehydes, 3 ketones, 4 fatty acids, 4 terpenes, 3 phenols, 3 furans, 1 acetal, and 1 C13-norisoprenoid compound. Each cider was composed of 36 to 53 of these volatile compounds. Moreover, sweet, sour, apple, cooked apple and yeasty were the most predominant sensory attributes (taste and aroma) to describe the similarities and differences of apple cider. Ciders from the Scandinavian region had diverse sensory profiles, whereas most of the UK apple ciders were characterized by these complex odors and taste, notes of 
sour, bitter and astringent. Moreover, apple cider characterized by cooked/fresh apple, citrus and tropical fruit odors had marked content of acetate esters. This group of compounds was more often present in sweet ciders from Normandy than those from Britany, reflecting important differences in the yeasts acting during the fermentation [147]. Other volatile compounds, like 4-ethylcatechol, could be used to differentiate the maturation stage of Asturian and Basque ciders [148].

Acidity has a low impact on volatile profile but is considered to be an essential element in cider and must be enough to give a clean and refreshing impression to the final products $[123,141,149]$. The most abundant acids in cider are lactic acid and malic acid, followed by citric acid and succinic acid [132,150,151].

Phenolic compounds are also important compounds of cider that contribute to notable differences in sensory quality of the ciders, such as astringency, bitterness or color [152-155]. Moreover, interactions between the volatile compounds and polyphenol matrix of cider may influence the release of volatile compounds [152].

The most abundant classes found in cider are hydroxycinnamic acid derivatives (phenylpropanoid structures), followed by different groups of flavonoids: flavan-3-ols proanthocyanidins, flavonols, and dihydrochalcones. While phenolic acids play an important role in the development of astringency and bitterness, the flavonoids, especially flavan-3-ols, influence the color, aroma and oxidative browning of ciders. Flavonols and dihydrochalcones are mainly related to the antioxidant properties of cider [90,156-158].

Volatile phenols are generally considered to be major markers of organoleptic defects of many fermented alcoholic beverages. The most problematic phenolic off-flavors causing defective ciders (4-ethylphenol, 4-vinylphenol, 4-ethylguaiacol, 4-vinylguaiacol and 4ethylcatechol) are produced by yeast, from caffeic, $p$-coumaric and ferulic acids $[159,160]$.

Cider apple pomace is also a valuable source of polyphenols, as flavanols, dihydrochalcones (phloridzin and phloretin-2'-xyloglucoside), flavonols and cinnamic acids (chlorogenic and caffeic acids) [63].

Apple cider vinegar is another apple fermented product that has polyphenolic compounds like catechin, caffeic acid, gallic acid, chlorogenic acids and p-coumaric acid [161].

Besides phenolic compounds, apple cider vinegar characteristics and fermentation quality are optimized by applying a nutrient feeding strategy. For example, Qi et al. [162] reported that using four specific amino acids (aspartate, glutamate, proline and tryptophan) is pivotal for optimizing nutritional composition of cider. They observed an improvement in the conversion into acetic acid by reducing the final concentrations of oxalic acid, tartaric acid, malic acid, lactic acid, citric acid and succinic acid. Additionally, the concentrations of most of the esters and volatile organic acids were also improved, thus contributing to the aromatic profile of the cider, particularly with respect to eight compounds: ethyl acetate, $\gamma$-methylbutyl ethanoate, caprylic acid, capric acid, phenylethyl alcohol, hexanoic acid, acetate-ethyl-2-methylpropanoate, and 2-phenylethyl ethyl acetate [162].

\section{Health Effects of Fermented Apple Products}

In general, fermented foods and beverages are considered safer than their unfermented counterparts, with this improved food safety owing to a great extent to the presence of $\mathrm{LAB}$, which is a predominant group of bacteria found in most fermented products [91]. The $\mathrm{LAB}$ act as probiotic bacteria, and they produce exopolysaccharides with several health benefits. Saadat et al. [163] present a comprehensive review regarding the health effects of these compounds, emphasizing the immunomodulatory effect and anti-cancer properties, high antioxidant activity, capacity to decrease blood glucose and cholesterol, anti-ulcer properties and antihypertensive activity [164-167].

Recent studies have shown the multiple health benefits brought with by apple vinegar consumption, such as attenuation of oxidative stress, reduction of obesity risk, balancing the cholesterol levels, antifungal activity $[168,169]$. Budak et al. [170] assessed the effect of consumption of apple cider vinegars obtained with different fermentation techniques (surface method with maceration, submersion method with maceration, surface method 
and submersion method) on the blood lipids in high-cholesterol fed rats. The addition of $10 \%$ apple pomace was used in the maceration step to increase the polyphenolic contents. The vinegars obtained by the surface method with and without maceration had the lowest $\mathrm{pH}$ values and the highest total phenolic contents. Apple cider vinegar obtained by the submersion method significantly decreased steatosis. The study proved that apple cider vinegar administration has beneficial effects on blood lipid levels, liver functions, steatosis and body weight. Beneficial effects of apple cider vinegar were recently proven based on a clinical trial considering weight management, visceral adiposity index and lipid profile in overweight or obese subjects [171].

Apple vinegar is rich in polyphenols and acetic acid, which have proven to be beneficial allies to modulate plasma lipid profile, glycemic indices or blood pressure [172]. Additionally, they reduce inflammation and the prevalence of diabetes $[173,174]$. These beneficial effects are associated with vinegar components; for example, it has been reported that intake of acetic acid though beverages helped lowering blood pressure in hypertensive patients $[175,176]$.

The review by Zhang et al. [177] highlights that fermented apple juice is rich in polyphenolic compounds, proven beneficial for the prevention of non-communicable diseases. The polyphenols profile and content in CAJ varies during the fermentation process and according to some variables, like apple variety, fermentation conditions or microorganisms' strains. Through enzymatic reaction, the long polyphenolic molecules are transformed into smaller compounds with stronger biological activity. These substances are described as being able to prevent cardiovascular diseases and type 2 diabetes by the different mechanisms described [177].

The study by Gheflati et al. [178] presented some confirmation that regular low dosage apple vinegar consumption can have beneficial effects on glycemic indices and oxidative stress in people suffering from diabetes and dyslipidemia. Studies have shown that the consumption of apple cider vinegar has positive effects on the management of diabetes [179]. Vinegar consumption can suppress postprandial hyperglycemia and can improve insulin resistance, in both healthy people as well as in people with diabetes [180-183].

The work by Asejeje et al. [184] suggests that apple cider vinegar has therapeutic potential by protecting against renal deficiency and connected malfunction, in an in vivo rat model.

Chiu et al. [185] carried out a double-blinded randomized clinical trial, aimed at comparing the performance of athletes who consumed apple cider vinegar with those who consumed a commercial sports drink [185]. Their results showed that apple cider vinegar had a similar effect to that of the commercial sports drink, both exhibiting ergogenic properties, enhanced blood glucose and improved non-esterified fatty acids, while suppressing the production of lactate. Both maintained normal respiratory exchange rate and heart beating throughout the endurance exercise.

Apple cider vinegar has been demonstrated to be a possible ally in weight management, helping in reducing appetite, anthropometric measures, visceral adiposity, blood triglycerides and total cholesterol levels, while increasing high-density lipoprotein cholesterol in overweight or obese patients [171,179]. Acetic acid has also been reported to be beneficial for intestinal health and fighting constipation [186].

The so-called hard cider is obtained from the fermentation of fresh unsterilized apples, and contains a variety of microorganism species, which are underexplored and constitute complex microbial populations. Ciders are naturally inoculated with different species, but these can change along the fermentation process. It is known that those rich microbial communities significantly impact the product characteristics but they can also benefit the consumer's health $[91,187]$.

It is possible that apples or apple juice used as raw material for cider production can be contaminated with pathogens derived from the orchard soil, from the farm or processing equipment or even form human sources. These pathogens may include Salmonella spp., Escherichia coli and Staphylococcus aureus. Nevertheless, because fermented cider is an acid 
product owing to the presence of organic acids (especially lactic acid), the low $\mathrm{pH}$ (ranging from 3.3 to 4.0 ) prevents the growth of these pathogens, which survive for a very short period and do not replicate [188].

Tyakht et al. [187] evaluated the bacterial and yeast microbiomes present in six samples of unpasteurized apple ciders resulting from non-industrialized artisanal processes. Since no bacteria are used as starter cultures for cider production, all bacterial detections were derived from spontaneous inoculation from the raw materials or the environment. The authors found a wide yeast diversity, accounting for many non-conventional species. Most abundant yeast species include not only Dekkera and Saccharomyces, but also other major taxa like Issatchenkia orientalis, Candida ethanolica, and Pichia spp. The most prevalent bacteria were LAB belonging to the Leuconostocaceae family, while the Lactobacillus were present in minor levels.

Cider, as with other alcoholic drinks, has to be consumed in moderation. Alcohol abuse is associated with increased occurrence of diseases, besides its negative social impact [189-192].

Cider ethanol content is very variable, commonly around 5-7\% [193], but sometimes even higher than 10\% [194], although there are also cases in which the technology is aimed at obtaining ciders with lower alcoholic content [195]. Another alcoholic drink made from fermented apple is brandy, produced traditionally in Romania, with an ethanol content of over $46 \%$ [112,196]. In the northern region of Sardinia, in Italy, distillates are produced from regional apples, producing apple brandy, [111]. "Calvados" is also distilled from cider in Normandy in northern France, and in the United Kingdom Somerset cider brandy is produced [197]. Besides ethanol, methanol can also be generated during the processing of these alcoholic beverages, under certain conditions and depending on the raw material used for their production [77]. Methanol content must be below a legal limit of $1.20 \mathrm{~g} \% \mathrm{~mL}$ p.A. established by EC Reg. No. 1014/90 and subsequent amendments [198].

Alcohol is absorbed when passing through the gastrointestinal system, moving to the liver and lungs to be metabolized. Methanol and its metabolites originate several health problems, besides direct toxicity, including oxidative stress as well as increased fatty acid ethyl ester accumulation. In the human body, methanol is metabolized into formaldehyde, which is toxic and responsible for carcinogenesis and neurologic complications [77,199-202]. Regarding ethanol, although it is not genotoxic or mutagenic, its metabolite acetaldehyde has been reported to be a dangerous carcinogen [189-192].

Some diseases associated with alcohol include steatosis (alcoholic fatty liver), alcoholic hepatitis, and fibrosis and/or liver cirrhosis [203]. In Europe, nearly $2 \%$ of all deaths occur as a consequence of liver disease. In fact, alcohol is the most important risk factor for alcoholic cirrhosis, and even light drinkers, i.e., those with a moderate consumption (corresponding to one to two drinks per day), have a higher risk of developing alcoholic cirrhosis when compared to abstainers [203,204].

In the study by Schutte et al. [205], alcoholic drinks such as cider were shown to be associated with increased risk for global mortality, cardiovascular problems, ischemic heart disease, cerebrovascular disease and cancer.

When the gut microbiota is altered due to the intake of alcoholic drinks, it contributes to the occurrence of diseases associated with alcohol. Nevertheless, this effect can be lightened by an adequate reposition of gut microbiome [189-191].

Apple cider and spirits can contain acrolein. The glycerol degradation in these and other apple-derived products can, by the action of lactic bacteria, lead to the formation of 3-hydroxypropanal, which is unstable and can spontaneously be transformed in acrolein $[197,206]$. Acrolein is an unsaturated aldehyde, with a high reactivity, which can frequently cause several diseases in humans [207-210].

There are other risks associated with apple cider, namely related with the possible presence of biogenic amines (BA). The malolactic fermentation has positive effects on the organoleptic properties of cider, but some LAB strains can also produce undesirable metabolites, like BA [211]. These BA can occur in foods or beverages involving fermentation, and are derived from the removal of the alpha carboxyl group from amino acids [212]. 
The most abundant BA found in cider include histamine, tyramine, putrescine and cadaverine (Figure 4), but their concentration is influenced by factors such as the type of microorganisms present, environmental conditions that include $\mathrm{pH}$, ethanol concentration, sulfur trioxide levels, quality of the raw material, the fermentation process and its technological conditions [211-215]. The ingestion of high levels of BAs can have harmful effects on the human body, causing adverse reactions like rashes, headaches or alter blood pressure (hypertension/hypotension). These effects are more problematic in people with health conditions that diminish their body detoxification capacity [91]. While histamine and tyramine are regarded as highly toxic and are therefore of particular importance in terms of food safety, it is also true that putrescine and cadaverine, although not so problematic in nature, can have a synergetic effect potentiating the harmful effects of BAs [215]. Because there is not a microbiological stabilization after malolactic fermentation in cider, the indigenous $\mathrm{LAB}$ constitute the predominant vehicles to promote the production of BAs $[214,216,217]$.

Histamine<smiles>NCCc1c[nH]cn1</smiles>

Tyramine

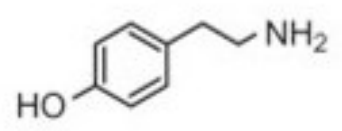

Putrescine

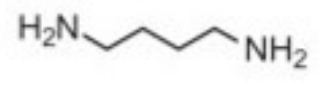

\section{Cadaverine}

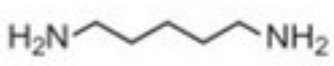

Figure 4. Most abundant biogenic amines found in cider.

Some apple-derived products can contain patulin, which is a toxic metabolite produced by certain yeast strains that bears several potential risks for human health [218-221]. Zhao et al. [222] studied a way to eliminate patulin from fermented apple puree by using specific fermentation conditions. They used for the fermentation a strain of Byssochlamys nivea that had previously been proved to have a high capacity to degrade patulin [223]. Their results confirmed that Patulin was degraded after 5 days at $37^{\circ} \mathrm{C}$ by the used yeast strain, providing that adequate temperature was maintained. Furthermore, they observed that $\mathrm{pH}$ practically did not influence patulin degradation. Hence, the fermented apple puree had improved health safety as compared with the non-fermented product.

Apple by-products, such as peels or pomace, constitute industrial wastes; these can, however, be used as sources of bioactive compounds, such as phenolic compounds with antioxidant activity [224]. Apple is rich in diverse bioactive phenolic compounds, most of them in higher concentrations in the peel, like, for example, epicatechin and quercetin glycosides [225-230]. Valorization processes can be used to obtain added value products, from which valuable compounds can be extracted. Gulsunoglu et al. [224] studied a method for the enhancement of polyphenolic compounds with antioxidant capacity in industrial apple waste by means of fermentation using several Aspergillus spp. Their results showed that $A$. niger and $A$. tubingensis produced eriodictyol, while $A$. japonicus and $A$. aculeatus produced taxifolin and catechin. These phenolic compounds have several health benefits: eriodictyol is a flavonoid with broad biological and pharmacological effects [231], including anti-inflammatory effect in osteoarthritis [232], cardioprotective effect [233], control of blood vessels permeability [234] and anti-allergic effect [235]; taxifolin is also a flavonoid with biological activities at different levels, showing antioxidant [236], antibacterial, anti-inflammatory [237] and antiviral [238] activities, improving microcirculation and regulating immunity, being used for treatment of atherosclerosis, dyslipidemia, cardiovascular diseases and other chronic diseases [239,240]; catechin, again in the class of flavonoids, has proven beneficial in cardiovascular health and showing several effects on the human body [241], like antioxidant [242], antihypertensive [243], anti-inflammatory [244], antiproliferative [245] and anti-hyperlipidemic [246]. 


\section{Final Remarks}

Apple is the basis for several fermented products, the most abundant being cider and vinegar, but also of relevance are spirits, particularly in some European countries, fermented juices, and probiotic beverages. Additionally, preferment apple pomace also makes it possible to produce added value products, while at the same time minimizing the impact of those residues that otherwise would be discarded. The fermentation technology and the yeast species used have a great impact on the final properties of the obtained fermented products, in terms of chemical composition, sensory profiles and effects on the human body, either beneficial or harmful. Some positive health effects of apple fermented products are associated with the presence of macro and micronutrients, as well as bioactive compounds (like phenolic compounds) and probiotic bacteria. On the other hand, some possible health problems can also arise due to the presence of methanol or biogenic amines. New developments in fermentation technology and studies on the use of different yeast species are continuously being made in order to improve profitability and the final qualities of the product, as well as to maximize their positive health effects. Future trends in this field will certainly encompass these developments, with the aim of increasing fermentation efficiency, optimizing the products obtained in terms of chemical composition, sensory properties and health benefits for humans, and also minimizing the potential risks associated with these fermented products. Additionally, fermentation can be expected to provide an alternative way to add value to residues from the food industry, and particularly with respect to apple, such as apple peels, seeds or low-quality raw materials. In this way, valorization of residues through fermentation can have positive economic and environmental impacts.

Author Contributions: Conceptualization, O.A., R.P.F.G.; methodology, O.A., R.P.F.G.; writingoriginal draft preparation, O.A., M.J.B., T.E.C., R.P.F.G.; writing—review and editing, O.A., M.J.B., T.E.C., E.B., R.P.F.G.; supervision, O.A., R.P.F.G.; funding acquisition, O.A. All authors have read and agreed to the published version of the manuscript.

Funding: APC was funded by Instituto Politécnico de Castelo Branco.

Institutional Review Board Statement: Not applicable.

Informed Consent Statement: Not applicable.

Acknowledgments: Thanks to Forest Research Centre (CEF), a research unit funded by Fundação para a Ciência e a Tecnologia I.P. (FCT), Portugal (UIDB/00239/2020). This work was supported by the FCT-Foundation for Science and Technology, I.P., within the scope of the project Refa UIDB /00681/ 2020. Furthermore, we would like to thank the CERNAS Research Centre and the Polytechnic Institute of Viseu for their support.

Conflicts of Interest: The authors declare that they do not have any conflicts of interest.

\section{References}

1. Li, Y.; Zhang, X.; Nie, J.; Bacha, S.A.S.; Yan, Z.; Gao, G. Occurrence and co-occurrence of mycotoxins in apple and apple products from China. Food Control. 2020, 118, 107354. [CrossRef]

2. Zhang, L.; Hu, J.; Han, X.; Li, J.; Gao, Y.; Richards, C.; Zhang, C.; Tian, Y.; Liu, G.; Gul, H.; et al. A high-quality apple genome assembly reveals the association of a retrotransposon and red fruit colour. Nat. Commun. 2019, 10, 1-13. [CrossRef] [PubMed]

3. Food and Agriculture Organization. FAOSTAT. Available online: http://www.fao.org/faostat/en/\#data/QL (accessed on 5 November 2020).

4. Bars-Cortina, D.; Macià, A.; Iglesias, I.; Garanto, X.; Badiella, L.; Motilva, M.J. Seasonal Variability of the Phytochemical Composition of New Red-Fleshed Apple Varieties Compared with Traditional and New White-Fleshed Varieties. J. Agric. Food Chem. 2018, 66, 10011-10025. [CrossRef] [PubMed]

5. Bars-Cortina, D.; Martínez-Bardají, A.; Macià, A.; Motilva, M.J.; Piñol-Felis, C. Consumption evaluation of one apple flesh a day in the initial phases prior to adenoma/adenocarcinoma in an azoxymethane rat colon carcinogenesis model. J. Nutr. Biochem. 2020, 83, 108418. [CrossRef] [PubMed]

6. Mohebbi, S.; Babalar, M.; Zamani, Z.; Askari, M.A. Influence of early season boron spraying and postharvest calcium dip treatment on cell-wall degrading enzymes and fruit firmness in 'Starking Delicious' apple during storage. Sci. Hortic. 2020, 259, 108822. [CrossRef] 
7. Bílková, A.; Bad'urová, K.; Svobodová, P.; Vávra, R.; Jakubec, P.; Chocholouš, P.; Švec, F.; Sklenářová, H. Content of major phenolic compounds in apples: Benefits of ultra-low oxygen conditions in long-term storage. J. Food Compos. Anal. 2020, 92, 103587. [CrossRef]

8. Pruksasri, S.; Lanner, B.; Novalin, S. Nanofiltration as a potential process for the reduction of sugar in apple juices on an industrial scale. LWT 2020, 133, 110118. [CrossRef]

9. Sauceda-Gálvez, J.; Codina-Torrella, I.; Martinez-Garcia, M.; Hernández-Herrero, M.; Gervilla, R.; Roig-Sagués, A. Combined effects of ultra-high pressure homogenization and short-wave ultraviolet radiation on the properties of cloudy apple juice. $L W T$ 2021, 136, 110286. [CrossRef]

10. Kidoń, M.; Grabowska, J. Bioactive compounds, antioxidant activity, and sensory qualities of red-fleshed apples dried by different methods. LWT 2021, 136, 110302. [CrossRef]

11. Feng, L.; Xu, Y.; Xiao, Y.; Song, J.; Li, D.; Zhang, Z.; Liu, C.; Liu, C.; Jiang, N.; Zhang, M.; et al. Effects of pre-drying treatments combined with explosion puffing drying on the physicochemical properties, antioxidant activities and flavor characteristics of apples. Food Chem. 2021, 338, 128015. [CrossRef]

12. Cruz, A.C.; Guiné, R.P.; Gonçalves, J.C. Drying Kinetics and Product Quality for Convective Drying of Apples (cvs. Golden Delicious and Granny Smith). Int. J. Fruit Sci. 2015, 15, 54-78. [CrossRef]

13. Guiné, R.P.; Cruz, A.C.; Mendes, M. Convective Drying of Apples: Kinetic Study, Evaluation of Mass Transfer Properties and Data Analysis using Artificial Neural Networks. Int. J. Food Eng. 2014, 10, 281-299. [CrossRef]

14. Dobiáš, J.; Voldřich, M.; Čurda, D. Heating of canned fruits and vegetables: Deaeration and texture changes. J. Food Eng. 2006, 77, 421-425. [CrossRef]

15. Lan, W.; Bureau, S.; Chen, S.; Leca, A.; Renard, C.M.; Jaillais, B. Visible, near- and mid-infrared spectroscopy coupled with an innovative chemometric strategy to control apple puree quality. Food Control. 2021, 120, 107546. [CrossRef]

16. Lan, W.; Jaillais, B.; Leca, A.; Renard, C.M.; Bureau, S. A new application of NIR spectroscopy to describe and predict purees quality from the non-destructive apple measurements. Food Chem. 2020, 310, 125944. [CrossRef] [PubMed]

17. Peng, W.; Meng, D.; Yue, T.; Wang, Z.; Gao, Z. Effect of the apple cultivar on cloudy apple juice fermented by a mixture of Lactobacillus acidophilus, Lactobacillus plantarum, and Lactobacillus fermentum. Food Chem. 2020, 340, 127922. [CrossRef]

18. Roberts, D.; Reyes, V.; Bonilla, F.; Dzandu, B.; Liu, C.; Chouljenko, A.; Sathivel, S. Viability of Lactobacillus plantarum NCIMB 8826 in fermented apple juice under simulated gastric and intestinal conditions. LWT 2018, 97, 144-150. [CrossRef]

19. Chen, C.; Lu, Y.; Yu, H.; Chen, Z.; Tian, H. Influence of 4 lactic acid bacteria on the flavor profile of fermented apple juice. Food Biosci. 2019, 27, 30-36. [CrossRef]

20. Sousa, A.; Vareda, J.; Pereira, R.; Silva, C.; Câmara, J.S.; Câmara, J.S.; Perestrelo, R. Geographical differentiation of apple ciders based on volatile fingerprint. Food Res. Int. 2020, 137, 109550. [CrossRef]

21. Lobo, A.P.; Bedriñana, R.P.; Madrera, R.R.; Valles, B.S. Aromatic, olfactometric and consumer description of sweet ciders obtained by cryo-extraction. Food Chem. 2021, 338, 127829. [CrossRef]

22. Cusano, E.; Cagliani, L.R.; Consonni, R.; Simonato, B.; Zapparoli, G. NMR-based metabolic profiling of different yeast fermented apple juices. LWT 2020, 118, 108771. [CrossRef]

23. Bortolini, D.G.; Benvenutti, L.; Demiate, I.M.; Nogueira, A.; Alberti, A.; Zielinski, A.A.F. A new approach to the use of apple pomace in cider making for the recovery of phenolic compounds. LWT 2020, 126, 109316. [CrossRef]

24. Madrera, R.R.; Bedriñana, R.P.; Valles, B.S. Enhancement of the nutritional properties of apple pomace by fermentation with autochthonous yeasts. LWT-Food Sci. Technol. 2017, 79, 27-33. [CrossRef]

25. Jin, Q.; Qureshi, N.; Wang, H.; Huang, H. Acetone-butanol-ethanol (ABE) fermentation of soluble and hydrolyzed sugars in apple pomace by Clostridium beijerinckii P. Fuel 2019, 244, 536-544. [CrossRef]

26. Zheng, Z.; Shetty, K. Enhancement of pea (Pisum sativum) seedling vigour and associated phenolic content by extracts of apple pomace fermented with Trichoderma spp. Process. Biochem. 2000, 36, 79-84. [CrossRef]

27. Katz, S.E.; Pollan, M. The Art of Fermentation: An In-Depth Exploration of Essential Concepts and Processes from around the World; Worth.it: White River Junction, VT, USA, 2012.

28. Couto, S.R.; Sanromán, M. Ángeles Application of solid-state fermentation to food industry-A review. J. Food Eng. 2006, 76, 291-302. [CrossRef]

29. García, C.; Rendueles, M.; Díaz, L.A.G. Liquid-phase food fermentations with microbial consortia involving lactic acid bacteria: A review. Food Res. Int. 2019, 119, 207-220. [CrossRef]

30. Garro, M.S.; Rivas, F.P.; Garro, O.A. 3.10 - Solid State Fermentation in Food Processing: Advances in Reactor Design and Novel Applications. In Innovative Food Processing Technologies; Knoerzer, K., Muthukumarappan, K., Eds.; Elsevier: Oxford, UK, 2021; pp. 165-182.

31. Hassan, A.; Nelson, B. Invited review: Anaerobic fermentation of dairy food wastewater. J. Dairy Sci. 2012, 95, 6188-6203. [CrossRef]

32. Reihani, S.F.S.; Khosravi-Darani, K. Influencing factors on single-cell protein production by submerged fermentation: A review. Electron. J. Biotechnol. 2019, 37, 34-40. [CrossRef]

33. Gavala, H.N.; Gavala, H.N.; Skiadas, I.V. Reactor systems for syngas fermentation processes: A review. Chem. Eng. J. 2018, 348, 732-744. [CrossRef] 
34. Zhou, M.; Yan, B.; Wong, J.; Zhang, Y. Enhanced volatile fatty acids production from anaerobic fermentation of food waste: A mini-review focusing on acidogenic metabolic pathways. Bioresour. Technol. 2018, 248, 68-78. [CrossRef] [PubMed]

35. Peris, M.; Escuder-Gilabert, L. On-line monitoring of food fermentation processes using electronic noses and electronic tongues: A review. Anal. Chim. Acta 2013, 804, 29-36. [CrossRef] [PubMed]

36. Herranz, B.; Fernández-Jalao, I.; Álvarez, M.D.; Quiles, A.; Sánchez-Moreno, C.; Hernando, I.; De Ancos, B. Phenolic compounds, microstructure and viscosity of onion and apple products subjected to in vitro gastrointestinal digestion. Innov. Food Sci. Emerg. Technol. 2019, 51, 114-125. [CrossRef]

37. Wang, D.; Jiang, Y.; Sun-Waterhouse, D.-X.; Zhai, H.; Guan, H.; Rong, X.; Li, F.; Yu, J.-C.; Li, D. MicroRNA-based regulatory mechanisms underlying the synergistic antioxidant action of quercetin and catechin in H2O2-stimulated HepG2 cells: Roles of BACH1 in Nrf2-dependent pathways. Free. Radic. Biol. Med. 2020, 153, 122-131. [CrossRef] [PubMed]

38. Tian, C.; Liu, X.; Chang, Y.; Wang, R.; Lv, T.; Cui, C.; Liu, M. Investigation of the anti-inflammatory and antioxidant activities of luteolin, kaempferol, apigenin and quercetin. South Afr. J. Bot. 2021, 137, 257-264. [CrossRef]

39. Yong, H.; Bai, R.; Bi, F.; Liu, J.; Qin, Y.; Liu, J. Synthesis, characterization, antioxidant and antimicrobial activities of starch aldehyde-quercetin conjugate. Int. J. Biol. Macromol. 2020, 156, 462-470. [CrossRef]

40. Dimpfel, W. Rat electropharmacograms of the flavonoids rutin and quercetin in comparison to those of moclobemide and clinically used reference drugs suggest antidepressive and/or neuroprotective action. Phytomedicine 2009, 16, 287-294. [CrossRef]

41. Li, S.; Pei, Y.; Wang, W.; Liu, F.; Zheng, K.; Zhang, X. Quercetin suppresses the proliferation and metastasis of metastatic osteosarcoma cells by inhibiting parathyroid hormone receptor. Biomed. Pharmacother. 2019, 114, 108839. [CrossRef]

42. Imran, M.; Iqubal, M.K.; Imtiyaz, K.; Saleem, S.; Mittal, S.; Rizvi, M.M.A.; Ali, J.; Baboota, S. Topical nanostructured lipid carrier gel of quercetin and resveratrol: Formulation, optimization, in vitro and ex vivo study for the treatment of skin cancer. Int. J. Pharm. 2020, 587, 119705. [CrossRef]

43. Ishizawa, K.; Yoshizumi, M.; Kawai, Y.; Terao, J.; Kihira, Y.; Ikeda, Y.; Tomita, S.; Minakuchi, K.; Tsuchiya, K.; Tamaki, T. Pharmacology in Health Food: Metabolism of Quercetin In Vivo and Its Protective Effect Against Arteriosclerosis. J. Pharmacol. Sci. 2011, 115, 466-470. [CrossRef]

44. Ebrahimpour, S.; Zakeri, M.; Esmaeili, A. Crosstalk between obesity, diabetes, and alzheimer's disease: Introducing quercetin as an effective triple herbal medicine. Ageing Res. Rev. 2020, 62, 101095. [CrossRef] [PubMed]

45. Sahoo, P.K.; Pradhan, L.K.; Aparna, S.; Agarwal, K.; Banerjee, A.; Das, S.K. Quercetin abrogates bisphenol A induced altered neurobehavioral response and oxidative stress in zebrafish by modulating brain antioxidant defence system. Environ. Toxicol. Pharmacol. 2020, 80, 103483. [CrossRef] [PubMed]

46. DiNicolantonio, J.J.; Mccarty, M.F. Targeting Casein kinase 2 with quercetin or enzymatically modified isoquercitrin as a strategy for boosting the type 1 interferon response to viruses and promoting cardiovascular health. Med. Hypotheses 2020, 142, 109800. [CrossRef] [PubMed]

47. Wang, Y.; Tao, B.; Wan, Y.; Sun, Y.; Wangab, L.; Sun, J.; Li, C. Drug delivery based pharmacological enhancement and current insights of quercetin with therapeutic potential against oral diseases. Biomed. Pharmacother. 2020, 128, 110372. [CrossRef] [PubMed]

48. Boots, A.W.; Haenen, G.R.; Bast, A. Health effects of quercetin: From antioxidant to nutraceutical. Eur. J. Pharmacol. 2008, 585, 325-337. [CrossRef] [PubMed]

49. Veeriah, S.; Miene, C.; Habermann, N.; Hofmann, T.; Klenow, S.; Sauer, J.; Böhmer, F.; Wölfl, S.; Pool-Zobel, B.L. Apple polyphenols modulate expression of selected genes related to toxicological defence and stress response in human colon adenoma cells. Int. J. Cancer 2008, 122, 2647-2655. [CrossRef]

50. Chang, H.; Lei, L.; Zhou, Y.; Ye, F.; Zhao, G. Dietary Flavonoids and the Risk of Colorectal Cancer: An Updated Meta-Analysis of Epidemiological Studies. Nutrients 2018, 10, 950. [CrossRef]

51. He, X.; Wang, Y.; Hu, H.; Zhang, Z. In Vitro and in Vivo Antimammary Tumor Activities and Mechanisms of the Apple Total Triterpenoids. J. Agric. Food Chem. 2012, 60, 9430-9436. [CrossRef]

52. Chung, W.S.F.; Meijerink, M.; Zeuner, B.; Holck, J.; Louis, P.; Meyer, A.S.; Wells, J.M.; Flint, H.J.; Duncan, S.H. Prebiotic potential of pectin and pectic oligosaccharides to promote anti-inflammatory commensal bacteria in the human colon. FEMS Microbiol. Ecol. 2017, 93. [CrossRef]

53. Li, Y.; Wang, S.; Sun, Y.; Xu, W.; Zheng, H.; Wang, Y.; Tang, Y.; Gao, X.; Song, C.; Long, Y.; et al. Apple polysaccharide protects ICR mice against colitis associated colorectal cancer through the regulation of microbial dysbiosis. Carbohydr. Polym. 2020, $230,115726$. [CrossRef]

54. Williams, D.J.; Edwards, D.; Hamernig, I.; Jian, L.; James, A.P.; Johnson, S.K.; Tapsell, L.C. Vegetables containing phytochemicals with potential anti-obesity properties: A review. Food Res. Int. 2013, 52, 323-333. [CrossRef]

55. Guiné, R.P.; Florença, S.G.; Barroca, M.J.; Anjos, O. The duality of innovation and food development versus purely traditional foods. Trends Food Sci. Technol. 2021, 109, 16-24. [CrossRef]

56. Lyu, F.; Luiz, S.F.; Azeredo, D.R.P.; Cruz, A.G.; Ajlouni, S.; Ranadheera, C.S. Apple Pomace as a Functional and Healthy Ingredient in Food Products: A Review. Processes 2020, 8, 319. [CrossRef]

57. Perussello, A.C.; Zhang, Z.; Marzocchella, A.; Tiwari, B.K. Valorization of Apple Pomace by Extraction of Valuable Compounds. Compr. Rev. Food Sci. Food Saf. 2017, 16, 776-796. [CrossRef] 
58. Roberto, R.M.; Bedriñana, R.P.; Hevia, A.G.; Arce, M.B.; Valles, B.S. Production of spirits from dry apple pomace and selected yeasts. Food Bioprod. Process. 2013, 91, 623-631. [CrossRef]

59. May, C.D. Industrial pectins: Sources, production and applications. Carbohydr. Polym. 1990, 12, 79-99. [CrossRef]

60. Medeiros, A.B.; Pandey, A.; Freitas, R.J.; Christen, P.; Soccol, C.R. Optimization of the production of aroma compounds by Kluyveromyces marxianus in solid-state fermentation using factorial design and response surface methodology. Biochem. Eng. J. 2000, 6, 33-39. [CrossRef]

61. Grigelmo-Miguel, N.; Martín-Belloso, O. Comparison of Dietary Fibre from By-products of Processing Fruits and Greens and from Cereals. LWT Food Sci. Technol. 1999, 32, 503-508. [CrossRef]

62. Masoodi, F.; Sharma, B.; Chauhan, G. Use of apple pomace as a source of dietary fiber in cakes. Plant Foods Hum. Nutr. 2002, 57, 121-128. [CrossRef]

63. García, Y.D.; Valles, B.S.; Lobo, A.P. Phenolic and antioxidant composition of by-products from the cider industry: Apple pomace. Food Chem. 2009, 117, 731-738. [CrossRef]

64. Alibés, X.; Muñoz, F.; Rodriguez, J. Feeding value of apple pomace silage for sheep. Anim. Feed. Sci. Technol. 1984, 11, 189-197. [CrossRef]

65. Berovič, M.; Ostroveršnik, H. Production of Aspergillus niger pectolytic enzymes by solid state bioprocessing of apple pomace. J. Biotechnol. 1997, 53, 47-53. [CrossRef]

66. Daigle, P.; Gélinas, P.; Leblanc, D.; Morin, A. Production of aroma compounds by Geotrichum candidum on waste bread crumb. Food Microbiol. 1999, 16, 517-522. [CrossRef]

67. Villas-Boas, S.G.; Esposito, E.; De Mendonça, M.M. Novel lignocellulolytic ability of Candida utilis during solid-substrate cultivation on apple pomace. World J. Microbiol. Biotechnol. 2002, 18, 541-545. [CrossRef]

68. Jin, H.; Kim, H.-S.; Kim, S.-K.; Shin, M.-K.; Kim, J.-H.; Lee, J.-W. Production of heteropolysaccharide-7 by Beijerinckia indica from agro-industrial byproducts. Enzym. Microb. Technol. 2002, 30, 822-827. [CrossRef]

69. Canteri-Schemin, M.H.; Fertonani, H.C.R.; Waszczynskyj, N.; Wosiacki, G. Extraction of pectin from apple pomace. Braz. Arch. Biol. Technol. 2005, 48, 259-266. [CrossRef]

70. Bhushan, S.; Joshi, V. Baker's Yeast Production under Fed Batch Culture from Apple Pomace. J. Sci. Ind. Res. 2006, 65, 72-76.

71. Wang, X.; Kristo, E.; Lapointe, G. The effect of apple pomace on the texture, rheology and microstructure of set type yogurt. Food Hydrocoll. 2019, 91, 83-91. [CrossRef]

72. Dhillon, G.S.; Kaur, S.; Brar, S.K. Perspective of apple processing wastes as low-cost substrates for bioproduction of high value products: A review. Renew. Sustain. Energy Rev. 2013, 27, 789-805. [CrossRef]

73. Ricci, A.; Cirlini, M.; Guido, A.; Liberatore, C.M.; Ganino, T.; Lazzi, C.; Chiancone, B. From Byproduct to Resource: Fermented Apple Pomace as Beer Flavoring. Foods 2019, 8, 309. [CrossRef]

74. Li, S.; Nie, Y.; Ding, Y.; Zhao, J.; Tang, X. Effects of Pure and Mixed Koji Cultures with S accharomyces cerevisiae on Apple Homogenate Cider Fermentation. J. Food Process. Preserv. 2015, 39, 2421-2430. [CrossRef]

75. Madrera, R.R.; Bedriñana, R.P.; Valles, B.S. Production and characterization of aroma compounds from apple pomace by solid-state fermentation with selected yeasts. LWT 2015, 64, 1342-1353. [CrossRef]

76. Silva, M.; Macedo, A.; Malcata, F. Review: Steam distilled spirits from fermented grape pomace Revision: Bebidas destiladas obtenidas de la fermentación del orujo de uva. Food Sci. Technol. Int. 2000, 6, 285-300. [CrossRef]

77. Botelho, G.; Anjos, O.; Estevinho, L.M.; Caldeira, I. Methanol in Grape Derived, Fruit and Honey Spirits: A Critical Review on Source, Quality Control, and Legal Limits. Processes 2020, 8, 1609. [CrossRef]

78. AICV. European Cider Trends 2019; The European Cider \& Fruit Wine Association: Brussels, Belgium, 2019.

79. Nicolini, G.; Roman, T.; Carlin, S.; Malacarne, M.; Nardin, T.; Cossignani, L.; Larcher, R. Characterisation of single-variety still ciders produced with dessert apples in the Italian Alps. J. Inst. Brew. 2018, 124, 457-466. [CrossRef]

80. Ye, M.; Yue, T.; Yuan, Y. Changes in the profile of volatile compounds and amino acids during cider fermentation using dessert variety of apples. Eur. Food Res. Technol. 2014, 239, 67-77. [CrossRef]

81. Valles, B.S.; Bedriñana, R.P.; Queipo, A.L.; Alonso, J.J.M. Screening of cider yeasts for sparkling cider production (Champenoise method). Food Microbiol. 2008, 25, 690-697. [CrossRef]

82. Lobo, A.P.; Tascón, N.F.; Roberto, R.M.; Valles, B.S. Sensory and Foaming Properties of Sparkling Cider. J. Agric. Food Chem. 2005, 53, 10051-10056. [CrossRef]

83. Gomis, D.B.; Tamayo, D.M.; Valles, B.S.; Alonso, J.J.M. Detection of Apple Juice Concentrate in the Manufacture of Natural and Sparkling Cider by Means of HPLC Chemometric Sugar Analyses. J. Agric. Food Chem. 2004, 52, 201-203. [CrossRef]

84. Rosend, J.; Kaleda, A.; Kuldjärv, R.; Arju, G.; Nisamedtinov, I. The Effect of Apple Juice Concentration on Cider Fermentation and Properties of the Final Product. Foods 2020, 9, 1401. [CrossRef]

85. Tarko, T.; Duda-Chodak, A.; Sroka, P.; Januszek, M. Effect of Musts Oxygenation at Various Stages of Cider Production on Oenological Parameters, Antioxidant Activity, and Profile of Volatile Cider Compounds. Biomolecules 2020, 10, 890. [CrossRef] [PubMed]

86. Guyot, S.; Marnet, N.; Sanoner, P.; Drilleau, J.-F. Variability of the Polyphenolic Composition of Cider Apple (Malus domestica) Fruits and Juices. J. Agric. Food Chem. 2003, 51, 6240-6247. [CrossRef] [PubMed]

87. Nogueira, A.; Mongruel, C.; Simões, D.R.S.; Waszczynskyj, N.; Wosiacki, G. Effect of biomass reduction on the fermentation of cider. Braz. Arch. Biol. Technol. 2007, 50, 1083-1092. [CrossRef] 
88. Al Daccache, M.; Koubaa, M.; Salameh, D.; Maroun, R.G.; Louka, N.; Vorobiev, E. Ultrasound-assisted fermentation for cider production from Lebanese apples. Ultrason. Sonochem. 2020, 63, 104952. [CrossRef]

89. Lorenzini, M.; Simonato, B.; Slaghenaufi, D.; Ugliano, M.; Zapparoli, G. Assessment of yeasts for apple juice fermentation and production of cider volatile compounds. LWT 2019, 99, 224-230. [CrossRef]

90. Laaksonen, O.; Kuldjärv, R.; Paalme, T.; Virkki, M.; Yang, B. Impact of apple cultivar, ripening stage, fermentation type and yeast strain on phenolic composition of apple ciders. Food Chem. 2017, 233, 29-37. [CrossRef]

91. Cousin, F.J.; Le Guellec, R.; Schlusselhuber, M.; Dalmasso, M.; LaPlace, J.M.; Cretenet, M. Microorganisms in Fermented Apple Beverages: Current Knowledge and Future Directions. Microorganisms 2017, 5, 39. [CrossRef]

92. Abrahamse, C.E.; Bartowsky, E. Timing of malolactic fermentation inoculation in Shiraz grape must and wine: Influence on chemical composition. World J. Microbiol. Biotechnol. 2011, 28, 255-265. [CrossRef]

93. Sumby, K.M.; Grbin, P.R.; Jiranek, V. Implications of new research and technologies for malolactic fermentation in wine. Appl. Microbiol. Biotechnol. 2014, 98, 8111-8132. [CrossRef]

94. Sumby, K.M.; Bartle, L.; Grbin, P.R.; Jiranek, V. Measures to improve wine malolactic fermentation. Appl. Microbiol. Biotechnol. 2019, 103, 2033-2051. [CrossRef]

95. Betteridge, A.; Grbin, P.; Jiranek, V. Improving Oenococcus oeni to overcome challenges of wine malolactic fermentation. Trends Biotechnol. 2015, 33, 547-553. [CrossRef] [PubMed]

96. Bartowsky, E.; Costello, P.; Chambers, P. Emerging trends in the application of malolactic fermentation. Aust. J. Grape Wine Res. 2015, 21, 663-669. [CrossRef]

97. Sánchez, A.; Coton, M.; Coton, E.; Herrero, M.; García, L.A.; Díaz, M. Prevalent lactic acid bacteria in cider cellars and efficiency of Oenococcus oeni strains. Food Microbiol. 2012, 32, 32-37. [CrossRef] [PubMed]

98. Sánchez, A.; Rodríguez, R.; Coton, M.; Coton, E.; Herrero, M.; García, L.A.; Díaz, M. Population dynamics of lactic acid bacteria during spontaneous malolactic fermentation in industrial cider. Food Res. Int. 2010, 43, 2101-2107. [CrossRef]

99. Reuss, R.; Stratton, J.; Smith, D.; Read, P.; Cuppett, S.; Parkhurst, A. Malolactic Fermentation as a Technique for the Deacidification of Hard Apple Cider. J. Food Sci. 2010, 75, C74-C78. [CrossRef]

100. Li, C.X.; Zhao, X.H.; Zuo, W.F.; Zhang, T.L.; Zhang, Z.Y.; Chen, X. The effects of simultaneous and sequential inoculation of yeast and autochthonous Oenococcus oeni on the chemical composition of red-fleshed apple cider. LWT 2020, 124, 109184. [CrossRef]

101. Fan, W.; Xu, Y.; Yu, A. Influence of Oak Chips Geographical Origin, Toast Level, Dosage and Aging Time on Volatile Compounds of Apple Cider. J. Inst. Brew. 2006, 112, 255-263. [CrossRef]

102. Budak, H.N.; Guzel-Seydim, Z.B. Antioxidant activity and phenolic content of wine vinegars produced by two different techniques. J. Sci. Food Agric. 2010, 90, 2021-2026. [CrossRef]

103. Mudura, E.; Coldea, T.; Socaciu, C.; Ranga, F.; Pop, C.; Rotar, A.; Pasqualone, A. Brown beer vinegar: A potentially functional product based on its phenolic profile and antioxidant activity. J. Serbian Chem. Soc. 2018, 83, 19-30. [CrossRef]

104. Bakir, S.; Toydemir, G.; Boyacioglu, D.; Beekwilder, J.; Capanoglu, E. Fruit Antioxidants during Vinegar Processing: Changes in Content and in Vitro Bio-Accessibility. Int. J. Mol. Sci. 2016, 17, 1658. [CrossRef] [PubMed]

105. Joshi, V.K.; Sharma, S. Cider Vinegar: Microbiology, Technology and QualityVinegars of the World. In Vinegars of the World; Springer: Milan, Italy, 2009; pp. 196-207. ISBN 978-88-470-0866-3.

106. Alkorta, I.; Garbisu, C.; Llama, M.J.; Serra, J.L. Industrial applications of pectic enzymes: A review. Process. Biochem. 1998, 33, 21-28. [CrossRef]

107. Budak, N.H.; Aykin, E.; Seydim, A.C.; Greene, A.K.; Guzel-Seydim, Z.B. Functional Properties of Vinegar. J. Food Sci. 2014, 79, R757-R764. [CrossRef] [PubMed]

108. EC. Regulation (EC) No 110/2008 of the European Parliament and of the Council of 15 January 2008 on the Definition, Description, Presentation, Labelling and the Protection of Geographical Indications of Spirit Drinks and Repealing Council Regulation (EEC) No 1576/89; European Commission: Brussels, Belgium, 2008.

109. Januszek, M.; Satora, P.; Tarko, T. Oenological Characteristics of Fermented Apple Musts and Volatile Profile of Brandies Obtained from Different Apple Cultivars. Biomolecules 2020, 10, 853. [CrossRef] [PubMed]

110. Hang, Y.D.; Woodams, E.E. Influence of apple cultivar and juice pasteurization on hard cider and eau-de-vie methanol content. Bioresour. Technol. 2010, 101, 1396-1398. [CrossRef] [PubMed]

111. Versini, G.; Franco, M.; Moser, S.; Barchetti, P.; Manca, G. Characterisation of apple distillates from native varieties of Sardinia island and comparison with other Italian products. Food Chem. 2009, 113, 1176-1183. [CrossRef]

112. Coldea, T.E.; Socaciu, C.; Mudura, E.; Socaci, S.A.; Ranga, F.; Pop, C.R.; Vriesekoop, F.; Pasqualone, A. Volatile and phenolic profiles of traditional Romanian apple brandy after rapid ageing with different wood chips. Food Chem. 2020, $320,126643$. [CrossRef]

113. Small, R.W.; Couturier, M.; Godfrey, M. Beverage Basics: Understanding and Appreciating Wine, Beer, and Spirits, 1st ed.; Wiley: Hoboken, NJ, USA, 2011.

114. Roberto, R.M.; Lobo, A.P.; Alonso, J.J.M. Effect of cider maturation on the chemical and sensory characteristics of fresh cider spirits. Food Res. Int. 2010, 43, 70-78. [CrossRef]

115. Zhang, H.; Woodams, E.E.; Hang, Y.D. Influence of pectinase treatment on fruit spirits from apple mash, juice and pomace. Process. Biochem. 2011, 46, 1909-1913. [CrossRef] 
116. Anjos, O.; Santos, A.J.; Estevinho, L.M.; Caldeira, I. FTIR-ATR spectroscopy applied to quality control of grape-derived spirits. Food Chem. 2016, 205, 28-35. [CrossRef]

117. Iyer, B.K.; Ananthanarayan, L. Effect of $\alpha$-amylase addition on fermentation of idli-A popular south Indian cereal-Legumebased snack food. LWT 2008, 41, 1053-1059. [CrossRef]

118. Daeschel, M.A. Antimicrobial Substances from Lactic Acid Bacteria for Use as Food Preservatives. Food Technol. 1989, 43, 164-167.

119. Leroy, F.; De Vuyst, L. Lactic acid bacteria as functional starter cultures for the food fermentation industry. Trends Food Sci. Technol. 2004, 15, 67-78. [CrossRef]

120. Gomes, A.M.P.; Malcata, F.X. Bifidobacterium spp. and Lactobacillus acidophilus: Biological, biochemical, technological and therapeutical properties relevant for use as probiotics. Trends Food Sci. Technol. 1999, 10, 139-157. [CrossRef]

121. Ellendersen, L.D.S.N.; Granato, D.; Guergoletto, K.B.; Wosiacki, G. Development and sensory profile of a probiotic beverage from apple fermented with Lactobacillus casei. Eng. Life Sci. 2012, 12, 475-485. [CrossRef]

122. Dimitrovski, D.; Velickova, E.; Langerholc, T.; Winkelhausen, E. Apple juice as a medium for fermentation by the probiotic Lactobacillus plantarum PCS 26 strain. Ann. Microbiol. 2015, 65, 2161-2170. [CrossRef]

123. Braga, C.M.; Zielinski, A.A.F.; Da Silva, K.M.; De Souza, F.K.F.; Pietrowski, G.D.A.M.; Couto, M.; Granato, D.; Wosiacki, G.; Nogueira, A. Classification of juices and fermented beverages made from unripe, ripe and senescent apples based on the aromatic profile using chemometrics. Food Chem. 2013, 141, 967-974. [CrossRef] [PubMed]

124. Costa, M.G.M.; Fonteles, T.V.; De Jesus, A.L.T.; Rodrigues, S. Sonicated pineapple juice as substrate for L. casei cultivation for probiotic beverage development: Process optimisation and product stability. Food Chem. 2013, 139, 261-266. [CrossRef]

125. Pereira, A.L.F.; Maciel, T.C.; Rodrigues, S. Probiotic beverage from cashew apple juice fermented with Lactobacillus casei. Food Res. Int. 2011, 44, 1276-1283. [CrossRef]

126. Veron Ponce, H.E.; Gauffin Cano, M.P.; Fabersani Marrades, M.E.; Sanz, Y.; Isla, M.I.; Fernández Espinar, M.T.; Gil Ponce, J.V.; Torres Castaños, S. Cactus Pear (Opuntia Ficus-Indica) Juice Fermented with Autochthonous Lactobacillus Plantarum S-811. Food Funct. 2019. [CrossRef]

127. Wu, C.; Li, T.; Qi, J.; Jiang, T.; Xu, H.; Lei, H. Effects of lactic acid fermentation-based biotransformation on phenolic profiles, antioxidant capacity and flavor volatiles of apple juice. LWT 2020, 122, 109064. [CrossRef]

128. Filannino, P.; Azzi, L.; Cavoski, I.; Vincentini, O.; Rizzello, C.G.; Gobbetti, M.; Cagno, R. Exploitation of the health-promoting and sensory properties of organic pomegranate (Punica granatum L.) juice through lactic acid fermentation. Int. J. Food Microbiol. 2013, 163, 184-192. [CrossRef] [PubMed]

129. Kaprasob, R.; Kerdchoechuen, O.; Laohakunjit, N.; Sarkar, D.; Shetty, K. Fermentation-based biotransformation of bioactive phenolics and volatile compounds from cashew apple juice by select lactic acid bacteria. Process. Biochem. 2017, 59, 141-149. [CrossRef]

130. Jaros, D.; Thamke, I.; Raddatz, H.; Rohm, H. Single-cultivar cloudy juice made from table apples: An attempt to identify the driving force for sensory preference. Eur. Food Res. Technol. 2009, 229, 51-61. [CrossRef]

131. Gao, H.; Wen, J.-J.; Hu, J.-L.; Nie, Q.-X.; Chen, H.-H.; Nie, S.-P.; Xiong, T.; Xie, M.-Y. Momordica charantia juice with Lactobacillus plantarum fermentation: Chemical composition, antioxidant properties and aroma profile. Food Biosci. 2019, 29, 62-72. [CrossRef]

132. Qin, Z.; Petersen, M.A.; Bredie, W.L. Flavor profiling of apple ciders from the UK and Scandinavian region. Food Res. Int. 2018, 105, 713-723. [CrossRef] [PubMed]

133. Liu, X.; Deng, J.; Bi, J.; Wu, X.; Zhang, B. Cultivar classification of cloudy apple juices from substandard fruits in China based on aroma profile analyzed by HS-SPME/GC-MS. LWT 2019, 102, 304-309. [CrossRef]

134. Ricci, A.; Cirlini, M.; Levante, A.; Dall'Asta, C.; Galaverna, G.; Lazzi, C. Volatile profile of elderberry juice: Effect of lactic acid fermentation using L. plantarum, L. rhamnosus and L. casei strains. Food Res. Int. 2018, 105, 412-422. [CrossRef]

135. Ziadi, M.; Wathelet, J.P.; Marlier, M.; Hamdi, M.; Thonart, P. Analysis of Volatile Compounds Produced by 2 Strains ofLactococcus lactisIsolated from Leben (Tunisian Fermented Milk) Using Solid-Phase Microextraction-Gas Chromatography. J. Food Sci. 2008, 73, S247-S252. [CrossRef]

136. Andreu-Sevilla, A.J.; Mena, P.; Martí, N.; Viguera, C.G.; Carbonell-Barrachina, A. Volatile composition and descriptive sensory analysis of pomegranate juice and wine. Food Res. Int. 2013, 54, 246-254. [CrossRef]

137. Leguerinel, I.; Cleret, J.J.; Bourgeois, C.; Mafart, P. Yeast Strain and the Formation of Flavour Components In Cider. J. Inst. Brew. 1988, 94, 391-395. [CrossRef]

138. Mangas, J.J.; González, M.P.; Rodriguez, R.; Blanco, D. Solid-phase extraction and determination of trace aroma and flavour components in cider by GC-MS. Chromatographia 1996, 42, 101-105. [CrossRef]

139. Peng, B.; Li, F.; Cui, L.; Guo, Y. Effects of Fermentation Temperature on Key Aroma Compounds and Sensory Properties of Apple Wine. J. Food Sci. 2015, 80, S2937-S2943. [CrossRef] [PubMed]

140. Peng, B.; Yue, T.; Yuan, Y. Analysis of key aroma components in cider from Shaanxi (China)Fujiapple. Int. J. Food Sci. Technol. 2009, 44, 610-615. [CrossRef]

141. Riekstina-Dolge, R.; Kruma, Z.; Karklina, D.; Seglina, D. Influence of Different Yeast Strains on the Production of Volatile Compounds in Fermented Apple Juice. Res. Rural. Dev. Int. Sci. Conf. 2011, 1, 133-139.

142. Al Daccache, M.; Koubaa, M.; Maroun, R.G.; Salameh, D.; Louka, N.; Vorobiev, E. Impact of the Physicochemical Composition and Microbial Diversity in Apple Juice Fermentation Process: A Review. Molecules 2020, 25, 3698. [CrossRef] [PubMed] 
143. Aung, M.T.; Lee, P.-R.; Yu, B.; Liu, S.-Q. Cider fermentation with three Williopsis saturnus yeast strains and volatile changes. Ann. Microbiol. 2014, 65, 921-928. [CrossRef]

144. Peng, B.; Yue, T.; Yuan, Y. A fuzzy comprehensive evaluation for selecting yeast for cider making. Int. J. Food Sci. Technol. 2008, 43, 140-144. [CrossRef]

145. Wang, L.; Xu, Y.; Zhao, G.; Li, J. Rapid Analysis of Flavor Volatiles in Apple Wine Using Headspace Solid-Phase Microextraction. J. Inst. Brew. 2004, 110, 57-65. [CrossRef]

146. Rita, R.-D.; Zanda, K.; Daina, K.; Dalija, S. Composition of aroma compounds in fermented apple juice: Effect of apple variety, fermentation temperature and inoculated yeast concentration. Procedia Food Sci. 2011, 1, 1709-1716. [CrossRef]

147. Haider, W.; Barillier, D.; Hayat, A.; Gaillard, J.-L.; Ledauphin, J. Rapid quantification and comparison of major volatile compounds of ciders from France (Normandy and Brittany) using microextraction by packed sorbent (MEPS). Anal. Methods 2014, 6, 1364-1376. [CrossRef]

148. Lobo, A.P.; Antón-Díaz, M.J.; Alonso, J.J.M.; Valles, B.S. Characterization of Spanish ciders by means of chemical and olfactometric profiles and chemometrics. Food Chem. 2016, 213, 505-513. [CrossRef] [PubMed]

149. Vidrih, R.; Hribar, J. Synthesis of higher alcohols during cider processing. Food Chem. 1999, 67, 287-294. [CrossRef]

150. Picinelli, A.; Suárez, B.; Moreno, J.; Rodríguez, R.; Caso-García, L.M.; Mangas, J.J. Chemical Characterization of Asturian Cider. J. Agric. Food Chem. 2000, 48, 3997-4002. [CrossRef] [PubMed]

151. Ye, M.; Yue, T.; Yuan, Y. Evolution of polyphenols and organic acids during the fermentation of apple cider. J. Sci. Food Agric. 2014, 94, 2951-2957. [CrossRef] [PubMed]

152. Guo, J.; Yue, T.; Yuan, Y. Impact of polyphenols on the headspace concentration of aroma compounds in apple cider. J. Sci. Food Agric. 2019, 99, 1635-1642. [CrossRef] [PubMed]

153. Lea, A.G.H.; Arnold, G.M. The phenolics of ciders: Bitterness and astringency. J. Sci. Food Agric. 1978, 29, 478-483. [CrossRef]

154. Symoneaux, R.; Baron, A.; Marnet, N.; Bauduin, R.; Chollet, S. Impact of apple procyanidins on sensory perception in model cider (part 1): Polymerisation degree and concentration. LWT Food Sci. Technol. 2014, 57, 22-27. [CrossRef]

155. Verdu, C.F.; Childebrand, N.; Marnet, N.; LeBail, G.; Dupuis, F.; Laurens, F.; Guilet, D.; Guyot, S. Polyphenol variability in the fruits and juices of a cider apple progeny. J. Sci. Food Agric. 2013, 94, 1305-1314. [CrossRef]

156. Lachowicz, S.; Oszmiański, J.; Uździcka, M.; Chmielewska, J. The Influence of Yeast Strain, $\beta$-Cyclodextrin, and Storage Time on Concentrations of Phytochemical Components, Sensory Attributes, and Antioxidative Activity of Novel Red Apple Ciders. Molecules 2019, 24, 2477. [CrossRef]

157. Marks, S.C.; Mullen, W.; Crozier, A. Flavonoid and Hydroxycinnamate Profiles of English Apple Ciders. J. Agric. Food Chem. 2007, 55, 8723-8730. [CrossRef]

158. Lobo, A.P.; García, Y.D.; Mangas-Sanchez, J.; Roberto, R.M.; Valles, B.S. Phenolic and antioxidant composition of cider. J. Food Compos. Anal. 2009, 22, 644-648. [CrossRef]

159. Buron, N.; Guichard, H.; Coton, E.; Ledauphin, J.; Barillier, D. Evidence of 4-ethylcatechol as one of the main phenolic off-flavour markers in French ciders. Food Chem. 2011, 125, 542-548. [CrossRef]

160. Buron, N.; Coton, M.; Legendre, P.; Ledauphin, J.; Kientz-Bouchart, V.; Guichard, H.; Barillier, D.; Coton, E. Implications of Lactobacillus collinoides and Brettanomyces/Dekkera anomala in phenolic off-flavour defects of ciders. Int. J. Food Microbiol. 2012, 153, 159-165. [CrossRef]

161. Tripathi, S.; Mazumder, P.M. Apple Cider Vinegar (ACV) and their Pharmacological Approach towards Alzheimer's Disease (AD): A Review. Indian J. Pharm. Educ. Res. 2020, 54, s67-s74. [CrossRef]

162. Qi, Z.; Dong, D.; Yang, H.; Xia, X. Improving fermented quality of cider vinegar via rational nutrient feeding strategy. Food Chem. 2017, 224, 312-319. [CrossRef] [PubMed]

163. Saadat, Y.R.; Khosroushahi, A.Y.; Gargari, B.P. A comprehensive review of anticancer, immunomodulatory and health beneficial effects of the lactic acid bacteria exopolysaccharides. Carbohydr. Polym. 2019, 217, 79-89. [CrossRef] [PubMed]

164. Abid, Y.; Casillo, A.; Gharsallah, H.; Joulak, I.; Lanzetta, R.; Corsaro, M.M.; Attia, H.; Azabou, S. Production and structural characterization of exopolysaccharides from newly isolated probiotic lactic acid bacteria. Int. J. Biol. Macromol. 2018, 108, 719-728. [CrossRef] [PubMed]

165. Oleksy, M.; Klewicka, E. Exopolysaccharides produced byLactobacillussp.: Biosynthesis and applications. Crit. Rev. Food Sci. Nutr. 2016, 58, 1-13. [CrossRef] [PubMed]

166. Nwodo, U.U.; Green, E.; Okoh, A.I. Bacterial Exopolysaccharides: Functionality and Prospects. Int. J. Mol. Sci. 2012, 13, 14002-14015. [CrossRef]

167. Cirrincione, S.; Breuer, Y.; Mangiapane, E.; Mazzoli, R.; Pessione, E. ‘Ropy' phenotype, exopolysaccharides and metabolism: Study on food isolated potential probiotics LAB. Microbiol. Res. 2018, 214, 137-145. [CrossRef]

168. Halima, B.H.; Sonia, G.; Sarra, K.; Houda, B.J.; Fethi, B.S.; Abdallah, A. Apple Cider Vinegar Attenuates Oxidative Stress and Reduces the Risk of Obesity in High-Fat-Fed Male Wistar Rats. J. Med. Food 2018, 21, 70-80. [CrossRef] [PubMed]

169. Mota, A.C.L.G.; De Castro, R.D.; Oliveira, J.D.A.; Lima, E.D.O. Antifungal Activity of Apple Cider Vinegar on Candida Species Involved in Denture Stomatitis. J. Prosthodont. 2015, 24, 296-302. [CrossRef] [PubMed]

170. Budak, N.H.; Doguc, D.K.; Savas, C.M.; Seydim, A.C.; Tas, T.K.; Ciris, M.I.; Guzel-Seydim, Z.B. Effects of Apple Cider Vinegars Produced with Different Techniques on Blood Lipids in High-Cholesterol-Fed Rats. J. Agric. Food Chem. 2011, 59, 6638-6644. [CrossRef] [PubMed] 
171. Khezri, S.S.; Saidpour, A.; Hosseinzadeh, N.; Amiri, Z. Beneficial effects of Apple Cider Vinegar on weight management, Visceral Adiposity Index and lipid profile in overweight or obese subjects receiving restricted calorie diet: A randomized clinical trial. J. Funct. Foods 2018, 43, 95-102. [CrossRef]

172. Grosso, G.; Stepaniak, U.; Micek, A.; Stefler, D.; Bobak, M.; Pająk, A. Dietary polyphenols are inversely associated with metabolic syndrome in Polish adults of the HAPIEE study. Eur. J. Nutr. 2017, 56, 1409-1420. [CrossRef] [PubMed]

173. Pounis, G.; Bonaccio, M.; Di Castelnuovo, A.; Costanzo, S.; De Curtis, A.; Persichillo, M.; Sieri, S.; Donati, M.B.; Cerletti, C.; De Gaetano, G.; et al. Polyphenol intake is associated with low-grade inflammation, using a novel data analysis from the Moli-sani study. Thromb. Haemost. 2016, 115, 344-352. [CrossRef]

174. Salau, V.F.; Erukainure, O.L.; Islam, M.S. Chapter 29-Phenolics: Therapeutic applications against oxidative injury in obesity and type 2 diabetes pathology. In Pathology; Preedy, V.R., Ed.; Academic Press: London, UK, 2020; pp. $297-307$.

175. Sugiyama, S.; Kishi, M.; Fushimi, T.; Oshima, Y.; Kaga, T.; Kajimoto, O. Hypotensive Effect and Safety of Brown Rice Vinegar with High Concentration of GABA on Mild Hypertensive Subjects. Jpn. Pharmacol. Ther. 2008, 36, 429-444.

176. Kajimoto, O.; Ueno, H.; Nagata, Y.; Yabune, M.; Kajimoto, Y. Hypotensive Effects of Tablet Containing $\gamma$-Amino Butyric Acid (GABA) on High Normal Blood Pressure and Mild Hypertensive Subjects. Jpn. Pharmacol. Ther. 2004, 32, 929-944.

177. Zhang, S.; Hu, C.Y.; Guo, Y.; Wang, X.; Meng, Y. Polyphenols in fermented apple juice: Beneficial effects on human health. J. Funct. Foods 2021, 76, 104294. [CrossRef]

178. Gheflati, A.; Bashiri, R.; Ghadiri-Anari, A.; Reza, J.Z.; Kord, M.T.; Nadjarzadeh, A.; Bashiri, R. The effect of apple vinegar consumption on glycemic indices, blood pressure, oxidative stress, and homocysteine in patients with type 2 diabetes and dyslipidemia: A randomized controlled clinical trial. Clin. Nutr. ESPEN 2019, 33, 132-138. [CrossRef]

179. Shishehbor, F.; Mansoori, A.; Sarkaki, A.; Jalali, M.; Latifi, S. Apple Cider Vinegar Attenuates Lipid Profile in Normal and Diabetic Rats. Pak. J. Biol. Sci. 2008, 11, 2634-2638. [CrossRef] [PubMed]

180. Johnston, C.S.; Steplewska, I.; Long, C.A.; Harris, L.N.; Ryals, R.H. Examination of the Antiglycemic Properties of Vinegar in Healthy Adults. Ann. Nutr. Metab. 2010, 56, 74-79. [CrossRef] [PubMed]

181. Leeman, M.; Östman, E.; Björck, I. Vinegar dressing and cold storage of potatoes lowers postprandial glycaemic and insulinaemic responses in healthy subjects. Eur. J. Clin. Nutr. 2005, 59, 1266-1271. [CrossRef] [PubMed]

182. White, A.M.; Johnston, C.S. Vinegar Ingestion at Bedtime Moderates Waking Glucose Concentrations in Adults with WellControlled Type 2 Diabetes. Diabetes Care 2007, 30, 2814-2815. [CrossRef] [PubMed]

183. Santos, H.O.; De Moraes, W.M.; Da Silva, G.A.; Prestes, J.; Schoenfeld, B.J. Vinegar (acetic acid) intake on glucose metabolism: A narrative review. Clin. Nutr. ESPEN 2019, 32, 1-7. [CrossRef] [PubMed]

184. Asejeje, F.; Ighodaro, O.; Asejeje, G.; Adeosun, A. Protective role of apple cider vinegar (APCV) in CCl4-induced renal damage in wistar rats. Metab. Open 2020, 8, 100063. [CrossRef]

185. Chiu, H.-F.; Chiang, M.; Liao, H.-J.; Shen, Y.-C.; Venkatakrishnan, K.; Cheng, I.-S.; Wang, C.-K. The ergogenic activity of cider vinegar: A randomized cross-over, double-blind, clinical trial. Sports Med. Heal. Sci. 2020, 2, 38-43. [CrossRef]

186. Wang, L.; Cen, S.; Wang, G.; Lee, Y.-K.; Zhao, J.; Zhang, H.; Chen, W. Acetic acid and butyric acid released in large intestine play different roles in the alleviation of constipation. J. Funct. Foods 2020, 69, 103953. [CrossRef]

187. Tyakht, A.; Kopeliovich, A.; Klimenko, N.; Efimova, D.; Dovidchenko, N.; Odintsova, V.; Kleimenov, M.; Toshchakov, S.; Popova, A.; Khomyakova, M.; et al. Characteristics of bacterial and yeast microbiomes in spontaneous and mixed-fermentation beer and cider. Food Microbiol. 2021, 94, 103658. [CrossRef]

188. Jarvis, B. Cider (Cyder; Hard Cider). In Encyclopedia of Food Microbiology; Academic Press: Oxford, UK, $2014 ;$ pp. 437-443.

189. Lee, E.; Lee, J.-E. Impact of drinking alcohol on gut microbiota: Recent perspectives on ethanol and alcoholic beverage. Curr. Opin. Food Sci. 2021, 37, 91-97. [CrossRef]

190. Salas-Salvadó, J.; Casas-Agustench, P.; Salas-Huetos, A. Cultural and Historical Aspects of Mediterranean Nuts with Emphasis on Their Attributed Healthy and Nutritional Properties. Nutr. Metab. Cardiovasc. Dis. 2011, 21 (Suppl. 1), S1-S6. [CrossRef] [PubMed]

191. Salaspuro, M. Key role of local acetaldehyde in upper GI tract carcinogenesis. Best Pract. Res. Clin. Gastroenterol. 2017, 31, 491-499. [CrossRef] [PubMed]

192. Agnoli, L.; Boeri, M.; Scarpa, R.; Capitello, R.; Begalli, D. Behavioural patterns in Mediterranean-style drinking: Generation Y preferences in alcoholic beverage consumption. J. Behav. Exp. Econ. 2018, 75, 117-125. [CrossRef]

193. He, W.; Liu, S.; Heponiemi, P.; Heinonen, M.; Marsol-Vall, A.; Ma, X.; Yang, B.; Laaksonen, O. Effect of Saccharomyces cerevisiae and Schizosaccharomyces pombe strains on chemical composition and sensory quality of ciders made from Finnish apple cultivars. Food Chem. 2021, 345, 128833. [CrossRef] [PubMed]

194. Bedriñana, R.P.; Alonso, J.M.; Valles, B.S. Evaluation of autochthonous Saccharomyces bayanus strains under stress conditions for making ice ciders. LWT 2017, 81, 217-225. [CrossRef]

195. Al Daccache, M.; Koubaa, M.; Salameh, D.; Vorobiev, E.; Maroun, R.G.; Louka, N. Control of the sugar/ethanol conversion rate during moderate pulsed electric field-assisted fermentation of a Hanseniaspora sp. strain to produce low-alcohol cider. Innov. Food Sci. Emerg. Technol. 2020, 59, 102258. [CrossRef]

196. Coldea, T.E.; Socaciu, C.; Moldovan, Z.; Mudura, E. Minor Volatile Compounds in Traditional Homemade Fruit Brandies from Transylvania-Romania, as Determined by GC-MS Analysis. Not. Bot. Horti Agrobot. Cluj-Napoca 2014, 42, 530-537. [CrossRef] 
197. Ledauphin, J.; Lefrancois, A.; Marquet, N.; Beljean-Leymarie, M.; Barillier, D. Development of an accurate and sensitive gas chromatographic method for the determination of acrolein content in Calvados and cider. LWT 2006, 39, 1045-1052. [CrossRef]

198. EC. Regulation (EEC) No 1014/90 of 24 April 1990 Laying down Detailed Implementing Rules on the Definition, Description and Presentation of Spirit Drinks; European Commission: Brussels, Belgium, 1990.

199. Cederbaum, A.I. Alcohol Metabolism. Clin. Liver Dis. 2012, 16, 667-685. [CrossRef]

200. Tulpule, K.; Dringen, R. Formate generated by cellular oxidation of formaldehyde accelerates the glycolytic flux in cultured astrocytes. Glia 2012, 60, 582-593. [CrossRef]

201. Choi, J.-H.; Lee, S.K.; Gil, Y.-E.; Ryu, J.; Jung-Choi, K.; Kim, H.; Choi, J.Y.; Park, S.A.; Lee, H.W.; Yun, J.Y. Neurological Complications Resulting from Non-Oral Occupational Methanol Poisoning. J. Korean Med Sci. 2017, 32, 371-376. [CrossRef] [PubMed]

202. Elkhamary, S.M.; Fahmy, D.M.; Galvez-Ruiz, A.; Asghar, N.; Bosley, T.M. Spectrum of MRI findings in 58 patients with methanol intoxication: Long-term visual and neurological correlation. Egypt. J. Radiol. Nucl. Med. 2016, 47, 1049-1055. [CrossRef]

203. Yoon, Y.-H.; Chen, C.M.; Slater, M.E.; Jung, M.K.; White, A.M. Trends in Premature Deaths From Alcoholic Liver Disease in the U.S., 1999-2018. Am. J. Prev. Med. 2020, 59, 469-480. [CrossRef] [PubMed]

204. Askgaard, G.; Gronbaek, M.; Kjær, M.S.; Tjønneland, A.; Tolstrup, J.S. Alcohol drinking pattern and risk of alcoholic liver cirrhosis: A prospective cohort study. J. Hepatol. 2015, 62, 1061-1067. [CrossRef]

205. Schutte, R.; Papageorgiou, M.; Najlah, M.; Huisman, H.W.; Ricci, C.; Zhang, J.; Milner, N.; Schutte, A.E. Drink types unmask the health risks associated with alcohol intake-Prospective evidence from the general population. Clin. Nutr. 2020, 39, 3168-3174. [CrossRef] [PubMed]

206. Sauvageot, N.; Gouffi, K.; LaPlace, J.-M.; Auffray, Y. Glycerol metabolism in Lactobacillus collinoides: Production of 3hydroxypropionaldehyde, a precursor of acrolein. Int. J. Food Microbiol. 2000, 55, 167-170. [CrossRef]

207. Muguruma, K.; Pradipta, A.R.; Ode, Y.; Terashima, K.; Michiba, H.; Fujii, M.; Tanaka, K. Disease-associated acrolein: A possible diagnostic and therapeutic substrate for in vivo synthetic chemistry. Bioorganic Med. Chem. 2020, 28, 115831. [CrossRef]

208. Keshava, C.; Davis, J.A.; Stanek, J.; Thayer, K.A.; Galizia, A.; Keshava, N.; Gift, J.S.; Vulimiri, S.V.; Woodall, G.M.; Gigot, C.; et al. Application of systematic evidence mapping to assess the impact of new research when updating health reference values: A case example using acrolein. Environ. Int. 2020, 143, 105956. [CrossRef]

209. Woodruff, T.J.; Axelrad, D.A. Ambient Concentrations of Acrolein: Health Risks. In Encyclopedia of Environmental Health (Second Edition); Nriagu, J., Ed.; Elsevier: Oxford, UK, 2019; pp. 82-86.

210. Hong, J.-H.; Lee, P.A.H.; Lu, Y.-C.; Huang, C.-Y.; Chen, C.-H.; Chiang, C.-H.; Chow, P.-M.; Jaw, F.-S.; Wang, C.-C.; Huang, C.-Y.; et al. Acrolein contributes to urothelial carcinomas in patients with chronic kidney disease. Urol. Oncol. Semin. Orig. Investig. 2020, 38, 465-475. [CrossRef]

211. Costantini, A.; Pietroniro, R.; Doria, F.; Pessione, E.; García-Moruno, E. Putrescine production from different amino acid precursors by lactic acid bacteria from wine and cider. Int. J. Food Microbiol. 2013, 165, 11-17. [CrossRef]

212. Ladero, V.; Coton, M.; Fernández, M.; Buron, N.; Martín, M.C.; Guichard, H.; Coton, E.; Alvarez, M.A. Biogenic amines content in Spanish and French natural ciders: Application of qPCR for quantitative detection of biogenic amine-producers. Food Microbiol. 2011, 28, 554-561. [CrossRef] [PubMed]

213. Ladero, V.; Calles-Enriquez, M.; Fernandez, M.; Alvarez, M.A. Toxicological Effects of Dietary Biogenic Amines. Curr. Nutr. Food Sci. 2010, 6, 145-156. [CrossRef]

214. Coton, M.; Romano, A.; Spano, G.; Ziegler, K.; Vetrana, C.; Desmarais, C.; Lonvaud-Funel, A.; Lucas, P.; Coton, E. Occurrence of biogenic amine-forming lactic acid bacteria in wine and cider. Food Microbiol. 2010, 27, 1078-1085. [CrossRef] [PubMed]

215. Alvarez, M.A.; Moreno-Arribas, M.V. The problem of biogenic amines in fermented foods and the use of potential biogenic amine-degrading microorganisms as a solution. Trends Food Sci. Technol. 2014, 39, 146-155. [CrossRef]

216. Garai, G.; Dueñas, M.; Irastorza, A.; Moreno-Arribas, M.V. Biogenic amine production by lactic acid bacteria isolated from cider. Lett. Appl. Microbiol. 2007, 45, 473-478. [CrossRef]

217. Garai-Ibabe, G.; Irastorza, A.; Dueñas, M.T.; Martín-Álvarez, P.J.; Moreno-Arribas, V.M. Evolution of amino acids and biogenic amines in natural ciders as a function of the year and the manufacture steps. Int. J. Food Sci. Technol. 2012, 48, 375-381. [CrossRef]

218. Bullerman, L.B. MYCOTOXINS I Classifications. In Encyclopedia of Food Sciences and Nutrition (Second Edition); Caballero, B., Ed.; Academic Press: Oxford, UK, 2003; pp. 4080-4089.

219. Kharayat, B.S.; Singh, Y. Chapter 13-Mycotoxins in Foods: Mycotoxicoses, Detection, and Management. In Microbial Contamination and Food Degradation; Holban, A.M., Grumezescu, A.M., Eds.; Handbook of Food Bioengineering; Academic Press: London, UK, 2018; pp. 395-421.

220. Saleh, I.; Goktepe, I. Health risk assessment of Patulin intake through apples and apple-based foods sold in Qatar. Heliyon 2019, 5, e02754. [CrossRef]

221. Wei, C.; Yu, L.; Qiao, N.; Zhao, J.; Zhang, H.; Zhai, Q.; Tian, F.; Chen, W. Progress in the distribution, toxicity, control, and detoxification of patulin: A review. Toxicon 2020, 184, 83-93. [CrossRef] [PubMed]

222. Zhao, G.; Yang, X.; Nisar, T.; Tian, Y.; Sun, L.; Zhang, X.; Guo, Y. Patulin biodegradation and quality improvement of apple puree fermented with Byssochlamys nivea FF1-2. Food Biosci. 2018, 21, 45-52. [CrossRef]

223. Zhang, X.; Guo, Y.; Ma, Y.; Chai, Y.; Li, Y. Biodegradation of patulin by a Byssochlamys nivea strain. Food Control. 2016, 64, 142-150. [CrossRef] 
224. Gulsunoglu, Z.; Purves, R.W.; Karbancioglu-Guler, F.; Kilic-Akyilmaz, M. Enhancement of phenolic antioxidants in industrial apple waste by fermentation with Aspergillus spp. Biocatal. Agric. Biotechnol. 2020, 25, 101562. [CrossRef]

225. Marks, S.C.; Mullen, W.; Crozier, A. Flavonoid and chlorogenic acid profiles of English cider apples. J. Sci. Food Agric. 2007, 87, 719-728. [CrossRef]

226. Raudone, L.; Raudonis, R.; Liaudanskas, M.; Janulis, V.; Viskelis, P. Phenolic antioxidant profiles in the whole fruit, flesh and peel of apple cultivars grown in Lithuania. Sci. Hortic. 2017, 216, 186-192. [CrossRef]

227. Mihailović, N.R.; Mihailović, V.B.; Kreft, S.; Ćirić, A.R.; Joksović, L.G.; Đurđević, P.T. Analysis of phenolics in the peel and pulp of wild apples (Malus sylvestris (L.) Mill.). J. Food Compos. Anal. 2018, 67, 1-9. [CrossRef]

228. Lee, J.; Chan, B.L.S.; Mitchell, A.E. Identification/quantification of free and bound phenolic acids in peel and pulp of apples (Malus domestica) using high resolution mass spectrometry (HRMS). Food Chem. 2017, 215, 301-310. [CrossRef] [PubMed]

229. Bi, X.; Zhang, J.; Chen, C.; Zhang, D.; Li, P.; Ma, F. Anthocyanin contributes more to hydrogen peroxide scavenging than other phenolics in apple peel. Food Chem. 2014, 152, 205-209. [CrossRef]

230. Zhang, M.; Zhang, G.; You, Y.; Yang, C.; Li, P.; Ma, F. Effects of relative air humidity on the phenolic compounds contents and coloration in the 'Fuji' apple (Malus domestica Borkh.) peel. Sci. Hortic. 2016, 201, 18-23. [CrossRef]

231. Khlifi, R.; Dhaouefi, Z.; Maatouk, M.; Sassi, A.; Boudhiba, N.; Ioannou, I.; Ghedira, K.; Ghedira, L.C.; Kilani-Jaziri, S. Heat treatment improves the immunomodulatory and cellular antioxidant behavior of a natural flavanone: Eriodictyol. Int. Immunopharmacol. 2018, 61, 317-324. [CrossRef]

232. Wang, Y.; Chen, Y.; Chen, Y.; Zhou, B.; Shan, X.; Yang, G. Eriodictyol inhibits IL-1 $\beta$-induced inflammatory response in human osteoarthritis chondrocytes. Biomed. Pharmacother. 2018, 107, 1128-1134. [CrossRef]

233. Khan, M.K.; Huma, Z.E.; Dangles, O. A comprehensive review on flavanones, the major citrus polyphenols. J. Food Compos. Anal. 2014, 33, 85-104. [CrossRef]

234. Lee, J.K. Anti-inflammatory effects of eriodictyol in lipopolysaccharidestimulated raw 264.7 murine macrophages. Arch. Pharmacal Res. 2011, 34, 671-679. [CrossRef] [PubMed]

235. Yoo, J.-M.; Kim, J.-H.; Park, S.-J.; Kang, Y.-J.; Kim, T.-J. Inhibitory Effect of Eriodictyol on IgE/Ag-Induced Type I Hypersensitivity. Biosci. Biotechnol. Biochem. 2012, 76, 1285-1290. [CrossRef] [PubMed]

236. Rogovskiǔ, V.S.; Matiushin, A.I.; Shimanovskiǔ, N.L.; Semeǐkin, A.V.; Kukhareva, T.S.; Koroteev, A.M.; Koroteev, M.P.; Nifant'ev, E.E. Antiproliferative and antioxidant activity of new dihydroquercetin derivatives. Eksp Klin Farm. 2010, 73, 39-42.

237. Salama, S.A.; Kabel, A.M. Taxifolin ameliorates iron overload-induced hepatocellular injury: Modulating PI3K/AKT and p38 MAPK signaling, inflammatory response, and hepatocellular regeneration. Chem. Interact. 2020, 330, 109230. [CrossRef] [PubMed]

238. Galochkina, A.V.; Zarubaev, V.V.; Kiselev, I.O.; Babkin, B.A.; Ostroukhova, L.A. Antiviral Activity of The Dihydroquercetin During The Coxsackievirus B4 Replication In Vitro. Vopr. Virusol. 2016, 61, 27-31. [PubMed]

239. Gao, L.; Yuan, P.; Zhang, Q.; Fu, Y.; Hou, Y.; Wei, Y.; Zheng, X.; Feng, W. Taxifolin improves disorders of glucose metabolism and water-salt metabolism in kidney via PI3K/AKT signaling pathway in metabolic syndrome rats. Life Sci. 2020, $263,118713$. [CrossRef] [PubMed]

240. Plotnikov, M.B.; Aliev, O.I.; Sidekhmenova, A.V.; Shamanaev, A.Y.; Anishchenko, A.M.; Nosarev, A.V.; Pushkina, E.A. Modes of Hypotensive Action of Dihydroquercetin in Arterial Hypertension. Bull. Exp. Biol. Med. 2017, 162, 353-356. [CrossRef]

241. Zanwar, A.A.; Badole, S.L.; Shende, P.S.; Hegde, M.V.; Bodhankar, S.L. Chapter 21-Antioxidant Role of Catechin in Health and Disease. In Polyphenols in Human Health and Disease; Watson, R.R., Preedy, V.R., Zibadi, S., Eds.; Academic Press: San Diego, CA, USA, 2014; pp. 267-271.

242. Chen, W.; Zhu, X.; Lu, Q.; Zhang, L.; Wang, X.; Liu, R. C-ring cleavage metabolites of catechin and epicatechin enhanced antioxidant activities through intestinal microbiota. Food Res. Int. 2020, 135, 109271. [CrossRef]

243. Vechi, G.; de Cássia Melo Vilhena de Andrade Fonsecada Silva, R.; De Souza, P.; Da Silva, L.M.; De Andrade, S.F.; Filho, V.C. Cryptostrobin and catechin isolated from Eugenia mattosii D. Legrand leaves induce endothelium-dependent and independent relaxation in spontaneously hypertensive rat aorta. Pharmacol. Rep. 2019, 71, 950-957. [CrossRef]

244. Hodges, J.K.; Sasaki, G.Y.; Bruno, R.S. Anti-inflammatory Activities of Green Tea Catechins along the Gut-liver Axis in Nonalcoholic Fatty Liver Disease: Lessons Learned from Preclinical and Human Studies. J. Nutr. Biochem. 2020, 85, 108478. [CrossRef]

245. Cheng, Z.; Zhang, Z.; Han, Y.; Liu, J.; Wang, Y.; Chen, X.; Shao, Y.; Cheng, Y.; Zhou, W.; Lu, X.; et al. A review on anti-cancer effect of green tea catechins. J. Funct. Foods 2020, 74, 104172. [CrossRef]

246. Hui, C.K.; Majid, N.I.; Yusof, H.M.; Zainol, K.M.; Mohamad, H.; Zin, Z.M. Catechin profile and hypolipidemic activity of Morinda citrifolia leaf water extract. Heliyon 2020, 6, e04337. [CrossRef] 